\title{
ANALISA PENYEBAB TURUNNYA PRODUKSI KOPI ROBUSTA KABUPATEN TEMANGGUNG
}

\author{
Berliana Anggun Septiani \\ 222016078@student.uksw.edu \\ Istiarsi Saptuti Sri Kawuryan \\ Ilmu Ekonomi-Fakultas Ekonomika dan Bisnis-Universitas Kristen Satya Wacana
}

\begin{abstract}
Indonesia has a potency in the coffee sector. Many robusta coffee farmers really depending on the coffee sector. For the example, $75 \%$ of coffee farmers in Temanggung Regency work in the robusta coffee sector. Fluctuations and declining coffee production can be a burden for coffee potency optimization and decreasing the income of the coffee farmers. This study aims to determine the factors that can affect the declining of Robusta coffee production in Temanggung Regency. The analytical methods used in this study are Value Chain Analysis, Forward Linkage and Backward Linkage, and Fishbone Analysis. The author is using secondary and primary data. Secondary data was obtained from Statistics Indonesia and Directorate General of Plantations at the Ministry of Agriculture.Primary data was obtained from interviews with 3 key informans Robusta coffee farmers in Gesing Village who eligible. The result showed that age of plants and distance of each plants, lack of coffee picking services, weather and lack of cooperation and other sectors, such as the trade sector and the industrial sector can lead into a decreasing of coffee production.
\end{abstract}

Key words: declining of coffee production, robusta coffe, fishbone method

\begin{abstract}
ABSTRAK
Indonesia memiliki potensi pada komoditas kopi dan banyak tenaga kerja (petani kopi robusta) bergantung dengan komoditas kopi, hal tersebut ditunjukkan dengan $75 \%$ petani kopi di Kabupaten Temanggung bekerja pada komoditas kopi robusta. Terjadinya fluktuatif dan penurunan produksi kopi dapat menghambat pengoptimalan potensi kopi dan dapat menyebabkan penurunan pendapatan para petani kopi. Penelitian ini bertujuan untuk mengetahui faktor-faktor yang dapat mempengaruhi penurunan produksi kopi robusta di Kabupaten Temanggung. Metode analisis yang digunakan yaitu Analisis Value Chain, Forward Linkage dan Backward Linkage, serta Analisis Fishbone. Dengan menggunakan data sekunder dan primer. Data sekunder diperoleh dari Badan Pusat Statistik dan Statistik Perkebunan Indonesia komoditas kopi, sedangkan data primer diperoleh dari wawancara dengan petani kopi robusta di Desa Gesing, wawancara dilakukan pada 3 key informan yang telah memenuhi syarat. Hasil penelitian menunjukkan bahwa umur dan jarak tanaman, kurangnya jasa pemetik kopi, cuaca, serta kurangnya kerjasama dengan sektor-sektor lain, seperti sektor perdagangan dan sektor industri dapat mempengaruhi penurunan produksi kopi.
\end{abstract}

Kata kunci: penurunan produksi kopi, kopi robusta, metode fishbone

\section{PENDAHULUAN}

Kopi merupakan minuman yang digemari semua lapisan masyarakat mulai dari masyarakat dengan penghasilan rendah hingga masyarakat dengan penghasilan tinggi, masyarakat sudah terbiasa mengkonsumsi kopi sejak dahulu. Selain menjadi budaya konsumsi, ternyata kopi juga menja- di ritual adat, seperti di Keraton Solo, kopi dipercaya sebagai sesajen untuk minuman para dewa yang dilakukan setiap hari Selasa dan Kamis (Gumulya dan Helmi, 2017). Peran pentingnya kopi di Indonesia tak terlepas dari campur tangan Belanda yang pada saat itu membawa kopi ke Indonesia untuk pertama kalinya. 
Pada tahun 1696 untuk pertama kalinya kopi ada di Indonesia, yang dibawa oleh Komandan Pasukan Belanda. Pada saat itu, kopi yang dibawa ke Indonesia yaitu kopi Arabika. Ekspor kopi pertama Indonesia dilakukan oleh VOC pada tahun 1711 dan hingga pertengahan abad ke-19 kopi Jawa menjadi kopi terbaik di dunia, hambatan mulai muncul dengan adanya hama tanaman kopi, hingga pada akhirnya Belanda mendatangkan kopi Robusta agar lebih tahan dengan hama (Oktaviani, 2018). Setelah hindia belanda meninggalkan Indonesia, berbagai lahan kopi dikelola oleh penduduk Indonesia dan ekspor tetap dilakukan.

Pada tahun 2017 Indonesia menjadi negara penghasil kopi terbesar nomor empat di dunia, dengan total produksi $8 \%$ dari total produksi dunia, yaitu sebesar 639 ribu ton per tahun, yang terdiri atas $72,84 \%$ kopi Robusta dan 27,16\% kopi Arabika (Biro Humas Kemenperin dan Tim Komunikasi Pemerintah Kemkominfo, 2017).

Namun, berdasarkan perhitungan dengan Import Dependency Ratio (IDR) pada kurun waktu tahun 2010-2016 tingkat ketergantungan impor kopi Indonesia rata-rata sebesar 1,42 persen. Nilai tingkat ketergantungan import kopi Indonesia menunjukkan bahwa masih dibutuhkan kuantitas produksi kopi di Indonesia (Parnadi dan Loisa, 2018)

Konsumsi kopi nasional meningkat cukup pesat dalam 5 tahun terakhir, yaitu 8,8\% per tahun (Kementerian Koordinator Bidang Perekonomian Republik Indonesia, 2018). Peningkatan tersebut juga karena konsumsi kopi menjadi bagian dari gaya hidup masyarakat (Kementerian Koordinator Bidang Perekonomian Republik Indonesia, 2018). Namun dengan peluang tersebut, tidak diimbangi dengan pertumbuhan produksi kopi, sebab produksi justru cenderung stagnan bahkan turun, dengan rata-rata $-0,3 \%$ per tahun (Kementerian Koordinator Bidang Perekonomian Republik Indonesia, 2018). Dari hasil produksi kopi Indonesia, $70 \%$ kopi tersebut diekspor, namun karena permintaan di dalam negeri cukup tinggi, maka ekspor menurun (Syarifudin dan Endarwati, 2019). Sehingga, produsen kopi Indonesia belum mampu memenuhi permintaan secara agregat (Sarirahayu dan Aprianingsih, 2018).

Dengan berfluktuatifnya produksi kopi mengindikasikan perlunya penguatan pembangunan produksi kopi. Untuk menguatkan pembangunan produksi kopi Indonesia secara global perlu adanya penguatan pembangunan produksi kopi per wilayah.

Kopi merupakan salah satu komoditas perkebunan yang cukup berpotensi (Sari dan Nugroho, 2016), terutama jika dilihat dari proporsi luas lahan tanaman kopi. Pada tahun 2017 Jawa menjadi pulau yang memiliki lahan kopi terluas di Indonesia, yaitu dengan total 191,925 Ha atau 15,31\% dari seluruh luas lahan kopi di Indonesia (Badan Pusat Statistik, 2018b). Salah satu provinsi dengan potensi kopi di Jawa adalah Provinsi Jawa Tengah. Pada tahun 2017 luas lahan dan produksi kopi Provinsi Jawa Tengah menepati urutan ke dua di Jawa yaitu dengan luas lahan 40,531 Ha dengan total produksi 18,665 ton (Badan Pusat Statistik, 2018b).

Salah satu kabupaten yang cukup potensial di Jawa Tengah yaitu Kabupaten Temanggung. Produksi kopi Temanggung tergolong sebagai produksi terbesar di Jawa Tengah, karena sebesar $40 \%$ produksi kopi Jawa Tengah berasal dari Kabupaten Temanggung (Pemerintah Kabupaten Temanggung, 2017c).

Terdapat budidaya kopi jenis Robusta dan Arabika di Kabupaten Temanggung yang ditunjukkan pada gambar 1

Permintaan kopi Temanggung semakin lama semakin meningkat, baik permintaan domestik maupun permintaan luar negeri, namun Kabupaten Temanggung masih kewalahan dalam memenuhi permintaan karena produksi kopi yang masih kurang. Total ekspor kopi Temanggung sebanyak 200 ribu ton per tahun, dan kopi robusta Temanggung telah berkontribusi sebesar 60 persen terhadap ekspor Java Coffee ke Eropa, Asia, dan Amerika. Dengan permin- 
taan yang tinggi, luas perkebunan kopi di Temanggung hanya 12,800 ha, hal tersebut yang menyebabkan Temanggung masih kewalahan dalam memenuhi permintaan kopi (Pemerintah Kabupaten Temanggung, 2017a).

Terjadi peningkatan konsumsi kopi jenis Robusta, pada tahun 2010 konsumsi kopi jenis Robusta dunia hanya $35 \%$, namun pada tahun 2018 konsumsi mencapai 40-42 \% atau sekitar 65 juta karung (per karung yaitu 60 kilogram). Kebutuhan kopi Robusta dunia, per tahun rata-rata meningkat 58 ribu ton. Dalam 10 tahun terakhir terjadi kenaikan konsumsi kopi Robusta terutama di negaranegara Asia, karena penduduk Asia lebih menyukai cita rasa kopi Robusta (Ratnasari, 2018) dan 10 tahun yang akan datang volume ekspor kopi akan terus meningkat (Chandra et al., 2013).

Kopi robusta merupakan salah satu komoditas yang memiliki nilai strategis dalam upaya pemberdayaan ekonomi rakyat (Azmi dan Handriatni, 2018), dan berperan penting bagi pembangunan pedesaan (Sahat et al., 2018).

Besarnya potensi kopi Robusta diharapkan dapat meningkatkan kesejahteraan petani kopi dengan peningkatan dan pemerataan pendapatan petani kopi. Petani menjadi pengambil resiko dalam memanfaatkan keterbatasan lahan yang dimilikinya, sehingga petani harus mampu mengalokasikannya dengan optimal (Fitriani et al., 2020).

Namun dengan berbagai potensi kopi Robusta di Kabupaten Temanggung, seperti besarnya jumlah produksi kopi Robusta (dibandingkan dengan jumlah produksi kopi Arabika), luas lahan perkebunan (luas lahan perkebunan kopi Robusta $(9,316.19$ Ha) lebih besar dari pada luas lahan kopi Arabika (918.19 Ha) (Pemerintah Kabupaten Temanggung, 2017b); iklim; sumber daya manusia yang banyak, mengingat sebanyak $79 \%$ bekerja pada komoditas kopi Robusta (yang terdiri atas 34,400 orang petani kopi Robusta dan 8,962 orang petani kopi Arabika) (Pemerintah Kabupaten Temanggung, 2017b) dan adanya permintaan yang tinggi, namun produksi kopi Robusta Kabupaten Temanggung justru berfluktuatif dan terus mengalami penurunan sejak tahun 2014 hingga tahun 2017 (berdasarkan Gambar 1).

Berdasarkan teori produksi yang berkaitan dengan pertanian, upaya peningkatan produksi harus memperhatikan faktorfaktor penting dalam pengelolaan sumber daya produksi (Putri et al., 2018) untuk mengetahui faktor apa saja yang mempengaruhi penurunan produksi kopi Robusta Kabupaten Temanggung.

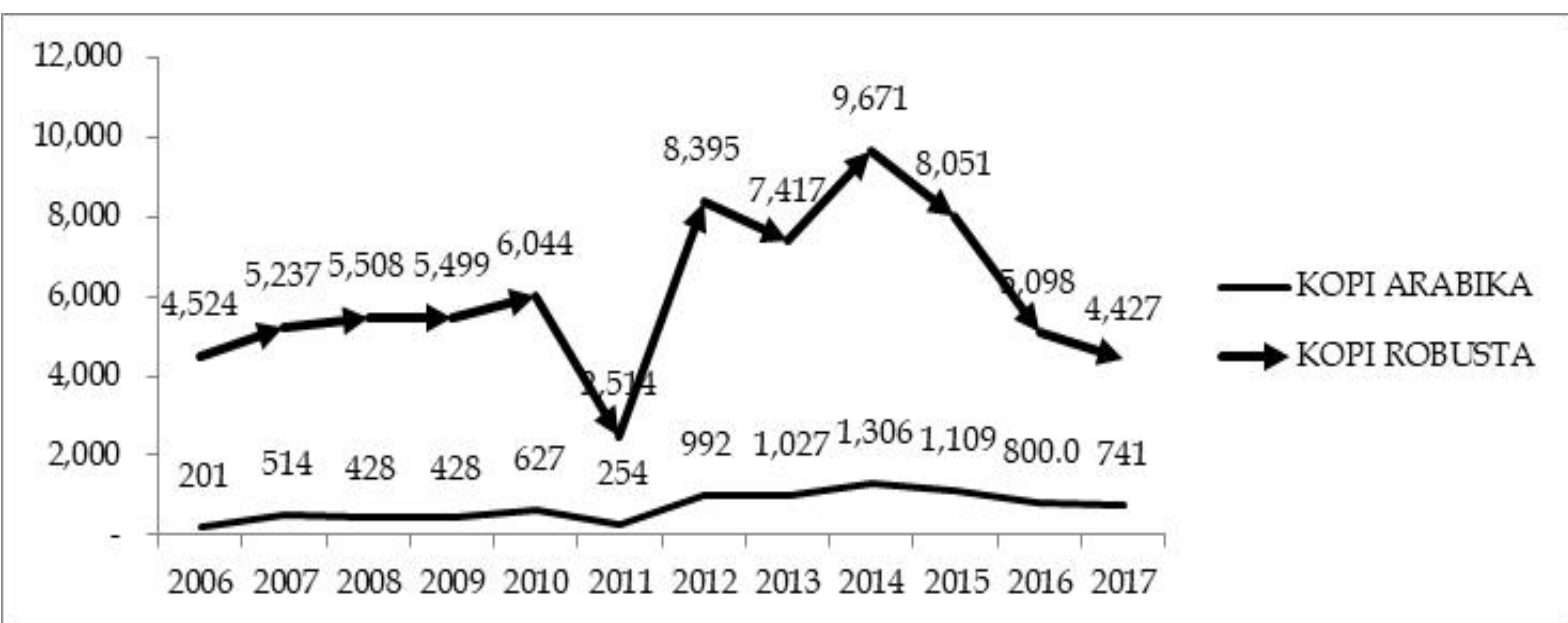

Gambar 1

Produksi Kopi Robusta dan Arabika Kabupaten Temanggung (ton), Pada Tahun 2006-2017

Sumber : Direktorat Jenderal Perkebunan (2015) 
Untuk mendapatkan hasil penelitian secara makro, metode penelitian yang dilakukan peneliti berbeda dari penelitianpenelitian sebelumnya yaitu dengan penelitian secara kualitatif dengan mengkombinasikan beberapa alat analisis untuk dapat menemukan faktor-faktor apa saja yang dapat mempengaruhi penurunan produksi kopi Robusta di Kabupaten Temanggung.

\section{TINJAUAN TEORETIS}

Teori Produksi bertumpu pada fungsi produksi, fungsi produksi menggambarkan hubungan antara faktor-faktor produksi (input) dengan hasil produksinya (output). Penentuan penggunaan faktor-faktor produksi merupakan hal yang penting dalam mencapai produksi yang tinggi dalam pertanian (Malik et al., 2019).

Metode analisis yang digunakan dalam penelitian ini berbeda dari penelitianpenelitian sebelumnya, dalam penelitian ini menggunakan metode analisis Value Chain, Backward Linkage dan Forward Linkage serta analisis Fishbone.

Alat analisis Value Chain (rantai nilai) merupakan suatu rangkaian yang harus dilakukan untuk mengembangkan suatu konsep menjadi barang dan jasa melalui suatu proses produksi (dilakukan dengan melibatkan kombinasi transformasi fisik dan input dari berbagai produsen jasa), pengiriman kepada konsumen akhir, dan perlakuan setelah produk tersebut digunakan. Di dalam rantai nilai, antar mata rantai saling berkaitan dengan mata rantai lainnya, dan tak jarang terjadi hubungan timbal balik antar rantai (Swarsingkin dan Budiani, 2015).

Terdapat keterkaitan ke belakang (backward linkage) dan keterkaitan ke depan (forward linkage) dalam suatu sistem pertanian. Keterkaitan ke belakang berlangsung karena subsistem usaha tani membutuhkan input produksi yang dapat diperoleh dengan cara membelinya dari pedagang sarana produksi yang ada di pasar, sedangkan adanya keterkaitan ke depan karena hasil produk pertanian dari subsistem usaha tani digunakan oleh industri pengolahan yang membutuhkannya sebagai bahan baku (Budi et al., 2016).

Sedangkan Diagram Fishbone yaitu alat untuk mengidentifikasi akar penyebab suatu masalah (Kristian, 2019). Diagram ini akan menunjukkan sebuah akibat (dampak) dari sebuah permasalahan, dengan berbagai penyebabnya. Bagian "akibat" dituliskan pada bagian moncong kepala, sedangkan "sebab-sebab sesuai dengan pendekatan permasalahannya" disusun pada bagian tulang ikan (Mustofa, 2014). Beberapa manfaat menyusun diagram Fishbone diantaranya dapat membantu menentukan akar penyebab masalah atau menggunakan pendekatan terstruktur, memanfaatkan pengetahuan kelompok tentang proses dan lebih sistematis (Huda, 2019).

Teori Produksi menyatakan bahwa produsen harus melakukan efisiensi untuk meningkatkan keuntungan. Namun menurut tulisan Pujianti (2019) faktor-faktor produksi (sebagai input) yang dimiliki oleh petani kopi masih terbatas, sehingga petani harus paham metode penggunaan/ pengalokasian faktor-faktor produksi kopi secara optimal, guna mencapai efisiensi untuk meningkatkan keuntungan dan kesejahteraan petani kopi.

Selain itu Fatma (2011) juga meneliti penurunan jumlah produksi kopi, dengan temuan terdapat hubungan searah antara jumlah produksi kopi dengan pendapatan petani, rendahnya jumlah produksi berakibat pada rendahnya pendapatan petani.

Berdasarkan penelitian-penelitian terdahulu yang menjadi landasan pengembangan penelitian ini, terdapat beberapa faktorfaktor produksi yang dapat berpengaruh terhadap produksi kopi, diantaranya modal (Ardiansah et al., 2014); (Mulyani, 2019); (Thana et al., 2021), jumlah tenaga kerja, lama pengalaman kerja (Putri et al., 2018), luas lahan (Andriani et al., 2012); (Sariani, 2017); (Yordy, 2017); (Abimanyu et al., 2018); (Haryoko et al., 2018), umur pohon kopi (Fatma, 2011), jumlah pohon, Herbisida 
(Simamora et al., 2017) serta pestisida dan pupuk yang terdiri atas pupuk kandang, (Isyariansyah et al., 2018), pupuk urea, dan pupuk Za (Thamrin, 2014).

Selain beberapa faktor input tersebut, juga terdapat faktor lain, seperti kurangnya informasi tentang harga jual produksi yang mengakibatkan peningkatan produksi yang pada akhirnya akan berpengaruh pada besarnya biaya yang dikeluarkan, sehingga berpengaruh pula pada pendapatan petani. Yang menjadi masalah yaitu harga jual kopi yang tidak menentu dari tahun ke tahun dan sering kurang menguntungkan bagi petani (Junaidi dan Hidayat, 2017).

Dengan adanya harga jual yang tak menentu dapat menyebabkan penurunan semangat dalam produksi, menurut Dahang dan Munthe, (2020) penurunan produksi kopi dapat terjadi karena perbedaan perlakuan budidaya. Berdasarkan penelitian Aklimawati et al., (2014); Kahpi (2017); Sarvina et al., (2020) kurangnya perhatian petani terhadap tanaman kopi, menyebabkan tanaman kopi tidak cukup dirawat dengan baik, maka tanaman kopi tidak dapat berproduksi secara optimum, sebab tanaman kopi akan tumbuh dengan liar.

Selain itu juga terdapat faktor lain yang dapat menyebabkan penurunan produksi kopi, yaitu meningkatnya kejadian iklim ekstrim (Läderach et al., 2017), seperti kekeringan akibat El Niño mengakibatkan penurunan produksi kopi $10 \%$, sedangkan musim hujan yang panjang akibat La Niña menurunkan produksi kopi hingga $80 \%$ (Syakir dan Surmaini, 2017), frekuensi curah hujan yang tinggi yang menyebabkan pembuahan kopi tidak terjadi (Prasetyo et al., 2017) dan menurut Ghini et al., (2011) iklim ekstrim menyebabkan perkembangan penyakit yang menurunkan $10 \%$ produksi pangan global. Perubahan iklim dapat mempersulit tercapainya target peningkatan produksi karena dengan adanya perubahan iklim menyebabkan munculnya serangan hama dan penyakit tanaman, sehingga produksi dan kualitas kopi dapat menurun (Syakir dan Surmaini, 2017).
Penelitian-penelitian tersebut dilakukan dengan uji regresi. Berbeda dari metode penelitian tersebut, dalam penelitian ini menggunakan pendekatan kualitatif dengan mengkombinasikan beberapa alat analisis untuk mendapatkan hasil penelitian secara makro.

\section{METODE PENELITIAN}

Penelitian dilakukan dengan menggunakan pendekatan kualitatif. Pendekatan kualitatif yaitu pendekatan yang menggunakan aspek-aspek kecenderungan, non perhitungan numerik, situasional deskriptif, interview mendalam, dan analisis isi di dalam usulan penelitian, proses, hipotesis, analisis data dan kesimpulan data hingga dengan penulisannya. Metode kualitatif fokus pada pengamatan yang mendalam (Gumilang, 2016). Metode yang digunakan adalah studi kasus, yaitu pengumpulan informasi/data yang dilakukan secara terinci dan intensif (mendalam) untuk menganalisis suatu peristiwa atau aktivitas baik secara individu maupunn kelompok.

Sumber data penelitian ini menggunakan data sekunder dan primer. Data sekunder diperoleh dari Statistik Perkebunan Indonesia komoditas kopi dan Badan Pusat Statistik, sedangkan data primer diperoleh dengan mendatangi secara langsung key informant pada lokasi penelitian dan penggunaan kuisioner sebagai alat pengumpulan data serta wawancara dan observasi untuk mendapatkan data yang lebih mendalam. Dengan melakukan wawancara dapat memperoleh data yang benar dan berguna dalam menjawab suatu fenomena (Leonard dan Needham, 2020). Hal tersebut dilakukan di Desa Gesing, Kecamatan Kandangan, Kabupaten Temanggung, karena memiliki produktivitas nomor dua dibandingkan dengan desa lain di Kecamatan Kandangan (Badan Pusat Statistik, 2018a), serta memiliki kualitas yang baik, hal ini terbukti dengan perolehan juara satu tingkat nasional gelaran Festival Kopi yang dihelat Himpunan Pengusaha Muda Indonesia (HIPMI) cabang Temanggung 
(Pemerintah Kabupaten Temanggung, 2017a).

Key informant dalam penelitian ini berjumlah 3 orang. Pemilihan ketiga key informant dipilih karena memenuhi kriteria yaitu mengetahui, memiliki informasi dan melakukan produksi kopi Robusta di Kabupaten Temanggung. Jumlah informan ditentukan oleh kelengkapan data yang dibutuhkan, jika informasi yang disampaikan oleh key informant masih kurang, maka menambah jumlah key informant hingga terpenuhi kelengkapan data. Untuk menjaga kerahasiaan identitas para key informant, nama-nama mereka dalam penelitian ini tidak disebutkan.

Teori yang digunakan dalam penelitian ini yaitu Teori Produksi. Untuk dapat memproduksi atau menghasilkan biji kopi robusta, terdapat beberapa langkah yang harus dilakukan oleh petani, petani harus mampu mengalokasikan input dengan tepat agar mampu menghasilkan output dengan maksimal. Menurut Pusat Penelitian dan Pengembangan Perkebunan (2010) dalam proses produksi kopi terdapat beberapa langkah yang dilakukan, yaitu:

1. Penyetekan

Penyetekan yaitu proses memperbanyak kopi untuk menumbuhkan akar entres kopi dengan menggunakan media tumbuh dan lingkungan (Pusat Penelitian dan Pengembangan Perkebunan, 2010).

\section{Penyambungan}

Merupakan penggabungan entres batang atas ke bibit batang bawah untuk memperbanyak kultivar unggul yang dikehendaki baik di lahan perkebunan maupun di pembibitan (Pusat Penelitian dan Pengembangan Perkebunan, 2010).

3. Pemupukan

Betujuan untuk menjaga daya tahan tanaman kopi, meningkatkan kualitas dan menjaga produksi kopi supaya stabil tinggi. Pemupukan harus dilakukan dengan tepat waktu, dosis dan jenis pupuk serta cara pemberiannya juga harus tepat (Pusat Penelitian dan Pengembangan Perkebunan, 2010). Penentuan penggunaan pupuk berguna baik untuk mendapat keuntungan, maupun keberlanjutan (Surya et al., 2017). Penggunaan pupuk yang berlebihan dapat mengancam keberlanjutan produksi kopi robusta (Byrareddy et al., 2019).

4. Pemangkasaan

Bermanfaat supaya pohon kopi tidak terlalu tinggi untuk mempermudah perawatannya, menumbuhkan cabang-cabang produksi yang baru, mempermudah masuknya cahaya matahari dan mempermudah pengendalian hama dan penyakit (Pusat Penelitian dan Pengembangan Perkebunan, 2010).

5. Pengendalian Hama dan Penyakit

Penurunan produktivitas kopi dapat disebabkan oleh beberapa factor-faktor, di antaranya disebabkan Organisme Pengganggu Tanaman (OPT). Terdapat tiga jenis OPT utama yang merusak tanaman kopi yaitu hama (Hama Penggerek Buah Kopi atau PBKO), nematoda parasit (Pratylenchus coffeae) dan penyakit (Penyakit Karat Daun Kopi) (Pusat Penelitian dan Pengembangan Perkebunan, 2010), penyakit karat dapat menurunkan hasil 20-70\% (Mahfud, 2012).

6. Sortasi buah kopi

Setelah buah kopi dipanen, perlu dilakukan sortasi, sortasi dilakukan dengan cara memisahkan buah dari kotoran, buah berpenyakit dan buah cacat. Pemisahan juga dilakukan antara buah yang berwarna merah dengan buah yang kuning atau hijau, juga pemisahan antara buah yang mulus, berwarna merah dan bernas (buah superior) dengan buah inferior. Sortasi bertujuan untuk mengklasifikasikan kualitas biji kopi yang dihasilkan (Pusat Penelitian dan Pengembangan Perkebunan, 2010).

7. Pengupasan kulit buah

Terdapat dua jenis mesin pengupas, yaitu pengupas yang diputar secara manual dan pengupas dengan tenaga mesin. Pada saat pengupasan kulit buah kopi, disarankan menggunakan mesin pengupas. Hasil dari proses pengupasan kulit buah yaitu biji HS (Hard Skin) biji tersebut masih terlapisi kulit tanduk, sehingga harus melalui tahapan lebih lanjut (Pusat Penelitian dan Pengembangan Perkebunan, 2010). 


\section{Fermentasi biji kopi HS}

Fermentasi dilakukan terhadap biji kopi HS. Terdapat dua cara pengupasan, cara pertama yaitu dengan perendaman biji kopi HS kedalam air bersih, kedua yaitu dengan menumpuk biji basah ke dalam bak semen atau bak kayu, kemudian atasnya ditutup dengan karung goni yang harus selalu dibasahi. Proses fermentasi pada lingkungan tropis berkisar antara 12-36 jam, apabila lapisan lender sudah hilang maka proses fermentasi berakhir. Setelah difermentasi, cuci kembali biji kopi tersebut dengan air, dengan cara membersihkan sisa-sisa lendir dan kulit buah yang masih menempel pada biji (Pusat Penelitian dan Pengembangan Perkebunan, 2010).

9. Pengeringan biji kopi HS

Biji kopi HS hasil dari proses fermentasi dikeringkan. Proses pengeringan dapat dilakukan dengan dijemur atau dengan mesin pengering. Sangat disarankan untuk melakukan pengeringan dengan menggunakan mesin untuk lebih efisien mengenai tenaga kerja dan waktu yang dibutuhkan (Pusat Penelitian dan Pengembangan Perkebunan, 2010).

10.Pengupasan kulit tanduk

Setelah biji kopi HS mencapai kadar air 12\%, langkah berikutnya yaitu pengupasan kulit tanduk yang masih menyelimuti biji kopi HS. Pengupasan bisa dilakukan dengan cara ditumbuk ataupun dengan bantuan mesin pengupas (huller). Untuk meminimalkan resiko kerusakan biji kopi, maka lebih disarankan untuk menggunakan mesin. Hasil pengupasan pada tahap ini disebut biji kopi beras (green bean) (Pusat Penelitian dan Pengembangan Perkebunan, 2010).

11. Sortasi akhir biji kopi

Tujuannya yaitu untuk memisahkan kotoran dan biji pecah.

12. Pengemasan dan Penyimpanan

Pengemasan biji kopi dilakukan dengan menggunakan karung yang bersih dan menjauhkan karung kopi tersebut dari aroma yang menyengat. Untuk penyimpanan jangka waktu yang lama, karungkarung kopi ditumpuk diatas palet kayu setebal $10 \mathrm{~cm}$, dan pemberian jarak antara tumpukan karung dengan dinding gudang. Kelembaban gudang sebaiknya pada kisaran kelembaban (RH) 70\%. Penggudangan berguna untuk menyimpan biji kopi sebelum didistribusikan kepada pembeli (Pusat Penelitian dan Pengembangan Perkebunan, 2010).

Duabelas langkah tersebutlah yang dilakukan petani kopi robusta dalam menghasilkan dan memaksimalkan ouput, yang juga dilakukan dengan memperbaiki dan menyempurnakan ketepatan input dan proses dalam pengelolaan kopi robusta.

Metode analisis yang digunakan Untuk menganalisis apa saja yang menjadi faktorfaktor yang dapat mempengaruhi penurunan produksi kopi Robusta di Kabupaten Temanggung yaitu Value Chain, Backward Linkage dan Forward Linkage serta analisis Fishbone. Penggunaan 3 alat analisis bertujuan supaya lebih akurat, dengan mengamati dan menganalisis menggunakan kolaborasi dari berbagai sudut pandang alat analisis.

\section{ANALISIS DAN PEMBAHASAN Proses Produksi}

Dalam suatu usaha perkebunan seorang petani harus berfikir untuk dapat mengalokasikan setiap input agar dapat menghasilakan output yang maksimal. Terdapat beberapa hal yang terdapat dalam input perkebunan kopi Robusta Kabupaten Temanggung, diantaranya lahan, tenaga kerja, bibit, pupuk, dan pestisida atau yang biasa dikenal dengan Saprotan (sarana produksi pertanian) (Budi et al., 2016); (Sachs et al., 2020), sedangkan dalam proses produksi kopi terdapat beberapa langkah yang dilakukan, yang ditampilkan pada gambar 2 . 


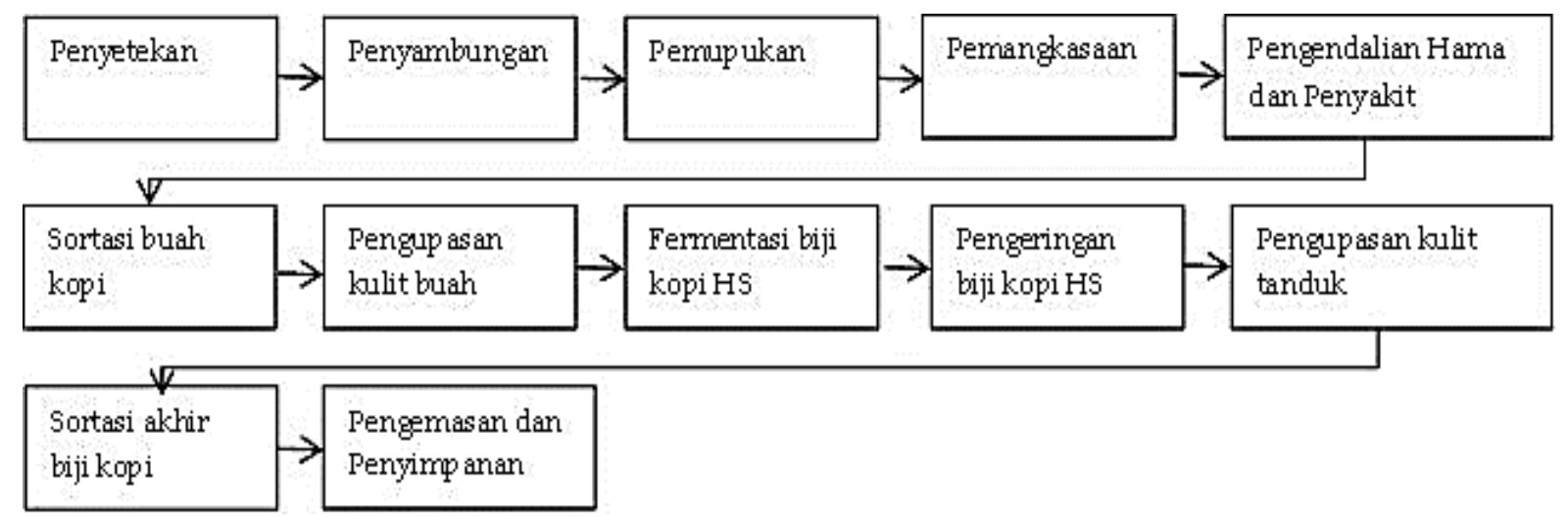

\section{Gambar 2}

Sumber: Pusat Penelitian dan Pengembangan Perkebunan (2010)

Proses Produksi Kopi

Dengan banyaknya langkah yang perlu dilakukan untuk dapat menghasilkan kopi Robusta, output yang dihasilkan akan tergantung dari ketepatan input dan proses yang dilakukan, sehingga setiap petani harus dapat menyadari apa saja yang menjadi penghambat dalam proses produksinya, baik hambatan yang terdapat pada input, proses maupun output, agar dapat mengatasi hambatan tersebut sehingga dapat mencapai tujuan produksi dengan optimal.

\section{Hasil Analisis dan Pembahasan Value Chain}

Perkebunan kopi di sekitar Kabupaten Temanggung masih mengandalkan pohon kopi yang sudah berumur puluhan tahun, pohon kopi tersebut merupakan warisan sejak tahun 1980-an. Umur pohon kopi mempengaruhi hasil produksi usaha tani kopi, usia pohon kopi paling produktif yaitu setelah berumur 9 tahun (Fatma, 2011), namun batas usia produktifnya yaitu 25 tahun (Evizal, 2013).

Modal yang digunakan dalam berkebun yaitu dari pendapatan panen periode sebelumnya (n-1). Apabila terjadi kekurangan modal, maka petani dapat dengan mudah memperoleh pinjaman dari perbankan ataupun dari petani lain (rekan dalam kelompok tani). Hal ini semakin dipermudah dengan adanya kartu tani yang ada sejak tahun 2017, petani dapat menun- jukkannya sebagai identitas untuk tujuan penggunaan pinjaman.

"Misal ada kebutuhan ya biasanya dari Kredit Usaha Rakyat (KUR), ada 50\% persen petani sini pake metode itu. Tapi ya ada juga yang $50 \%$ petani itu menggunakan simpenan kopinya untuk pemenuhan perawatan kopi, kan panen, mereka simpan hasil kopinya, jual perhari gitu. Gampang buat minjem KUR gampang". Disampaikan oleh key informant pertama.

Hal tersebut berbanding terbalik dengan hasil penelitian Universitas Diponegoro (2013) yang menyatakan bahwa akses modal kurang. Menurut Hasibuan (2014), modal dapat mempengaruhi produksi kopi.

Pada tahun 2011-2013 produksi kopi berfluktuatif, produksi paling tinggi terjadi pada tahun 2014, namun setelah itu terjadi penurunan. Dalam upaya meningkatkan produksi kopi, para petani Kabupaten Temanggung menjaga produktivitas pohon kopi, dengan melakukan pemangkasan batang, bukan langsung menebang pohon kopi (bukan tebang total), yang berarti apabila ada pohon kopi yang mati baru ditebang dan di ganti pohon yang baru, namun apabila pohon kopi tidak mati maka cukup dilakukan peremajaan batang saja.

Dua dari tiga petani kopi yang menjadi key informant dalam penelitian ini memiliki luas lahan yang tetap sejak puluhan tahun lalu, dan hanya 1 (satu) key informant yaitu key informant ketiga yang memperluas 
perkebunan kopi yang dimilikinya. Key informant pertama dan kedua hanya mengelola perkebunan milik pribadi, sedangkan key informant ketiga mengelola perkebunan Perhutani dan PT. Berdasarkan penelitian yang dilakukan oleh Haryoko et al., (2018); Yulanda (2019) luas lahan perkebunan berpengaruh signifikan positif terhadap produksi kopi, karena dengan memperluas lahan perkebunan kopi maka akan menambah jumlah produksi kopi Robusta.Siklus perawatan dan pemanenan kopi dilakukan setahun satu kali, diawali dengan pemangkasan batang (pangkas ringan) seperti tempel wiwilan atau satang cacing. Pemangkasan batang merupakan hal yang penting bagi petani di Kecamatan Kandangan, sebab pemangkasan batang dapat mempengaruhi jumlah kopi yang dihasilkan. Hal tersebut selaras dengan penelitian yang dilakukan oleh Nuddin et al., (2019) yang menjadikan rehabilitasi tanaman kopi dan peremajaan tanaman kopi sebagai strategi dalam mengembangkan produksi kopi robusta.

Setelah batang terbaru tumbuh dan lebat, pohon kopi akan lebih produktif dan dapat menghasilkan banyak kopi, siklus tersebut terjadi 2 tahun sekali, yang berarti bahwa 1 tahun tidak lebat dan 1 tahun kemudian lebat (dipengaruhi oleh kecepatan partumbuhan batang dalam menghasilkan bunga dan biji kopi paska pemangkasan). Hal tersebut yang menjadi alasan para petani kopi selalu melakukan pemangkasan, namun pemangkasan yang dilakukan antara petani kopi satu dengan petani yang lain tidak dilakukan serentak (tidak dilakukan di waktu yang sama), hal tersebut karena kondisi batang antar petani yang berbeda, pemangkasan dilakukan pada cabang tua, ataupun cabang yang terkena penyakit. Menurut key informant pertama, presentase cabang tua paling banyak yaitu sebesar $40 \%$.

Untuk membantu pertumbuhan batang, petani di Kabupaten Temanggung melakukan pemupukan. Hal tersebut didukung oleh penelitian yang dilakukan oleh Anggita et al., (2018); Isyariansyah et al., (2018) bahwa pupuk dapat berpengaruh terhadap produksi kopi Robusta, karena pupuk dapat memperbaiki kesuburan tanah (peningkatan unsur hara) dan akan meningkatkan proses produksi kopi. Menurut penelitian yang dilakukan oleh Pasaribu et al., (2019) secara serempak penggunaan/penentuan jumlah pupuk kandang dan pupuk NPK berpengaruh nyata terhadap produksi kopi Robusta.

Menurut seluruh key informant dalam penelitian ini, akses pupuk di Kabupaten Temanggung mudah dan penetapan pupuk subsidi juga dengan harga yang relatif sama dari tahun ketahun, pada pupuk Urea harga per karung (50 kg) yaitu Rp 91,000.00-, pada pupuk SP36 yaitu Rp 101,000.00- per karung (50 kg), pada pupuk ZA yaitu Rp 71,000.00per karung (50 kg) dan pada pupuk Phonska Rp 101,000.00- per karung (50 kg). Harga jual pupuk yang berlaku merupakan penetapan dari pemerintah, hal tersebut untuk menghindari tindak kecurangan oleh distributor pupuk (Pratiwi, 2016).

Sedangkan menurut Universitas Diponegoro (2013), penyediaan saprotan justru menjadi masalah yang ada pada input dari produksi kopi Robusta Kabupaten Temanggung, kuantitas saprotan terbatas dan masih dipasok dari luar daerah. Zat pengatur tumbuh diantaranya yaitu Rootone $\mathrm{F}$ dan Atonik atau juga dapat menggunakan air kelapa muda ataupun urin sapi. Hal ini berguna dalam upaya pemberian auksin eksogen (dari luar) yang dapat meningkatkan aktifitas auksin endogen yang sudah ada pada stek, sehingga akan mendorong pembelahan sel dan menyebabkan tunas muncul lebih awal (Sutedja, 2017). Menurut penelitian Universitas Diponegoro (2013) dari bebeberapa kebutuhan saprotan, yang menjadi hambatan utama pada produksi kopi Robusta Kabupaten Temanggung yaitu pupuk kimia.

Berdasarkan hasil penelitian, key informant pertama sebagai kepala kelompok tani menuturkan bahwa untuk mempermudah pendistribusian pupuk dari pemerintah, semua pupuk dikumpulkan menjadi 
satu dirumahnya, barulah petani-petani lain menebus dan mengambil di rumah key informant pertama. Penebusan dan pengambilan jatah pupuk tidak dilakukan sambarangan, harus memliki kartu tani dengan jumlah pupuk yang sudah disesuaikan. Pemberian pupuk subsidi disesuaikan sesuai dengan luas garapan yang tentunya sudah diverifikasi petugas lapangan, penerima subsidi maksimal memiliki luas 2 hektar, setiap 1 hektar mendapat sekitar $200 \mathrm{~kg}$ pupuk.

Dalam proses pertumbuhan bunga hingga buah kopi masak, petani Kecamatan Kandangan tidak menggunakan pestisida dalam mengantisipasi dan menghilangkan hama, namun hanya mengandalkan pemupukan yaitu dengan pupuk kimia (Urea, ZA, dan SP36) dan pupuk kandang. Berbeda dengan sebelum tahun 2014 yang terdapat hama kutu putih karena musim kemarau panjang, saat ini tidak ada serangan hama pada perkebunan kopi. Hama kutu putih menyebabkan kerugian besar karena menyerang pembungaan, kuncup bunga dan buah muda yang baru muncul menjadi kering dan gugur karena kutu mengisap tangkai bunga dan tangkaI buah (Sugiarti, 2019). Menurut penelitian yang dilakukan Oelviani dan Hermawan (2017) pengendalian Organisme Pengganggu Tanaman (OPT) mampu mempengaruhi produksi kopi.

"Pernah waktu itu sekitar 12 tahun lalu (2007) kemarau panjang, muncullah hama kutu putih, gara-gara kemarau panjang itu produksi bisa turun $70 \%$, biasanya ngilangin nya pake air, karena kami ga pake pestisida, cuma karna kemarau ya kekurangan air, kan jadinya kutunya susah ditangani, makanya produksi turun. Kalo kami pakenya ya pupuk itu tapi kan diawal dan akhir penghujan, kalo pestisida ya gak pake". Penuturan key informant pertama.

Hal tersebut selaras dengan yang disampaikan key informant kedua bahwa

"Pernah ada kemarau panjang, ada kutu putih mbak, itu (kutu putih) ya hilang setelah hujan. Gangguan produksi dari dulu sebelum dan sesudah tahun 2014 ya sama saja, banyak tidaknya (hasil produksi) ya tergantung cuaca, kalo hujannya pas dan kemarau nya pas ya hasilnya bagus". Hal tersebut disampaikan oleh key informant pertama.

Pada tahun 2013, curah hujan tinggi, hal tersebut menyebabkan penurunan produksi sebanyak 50\%, key informant menyampaikan bahwa penurunan produksi dikarenakan saat musim hujan berkepanjangan, maka terjadi bunga gugur, akibatnya buah biji kopi hanya sedikit yang berhasil bertahan hingga siap panen, penurunan produksi juga terjadi karena saat itu cabang yang masih berusia muda (paska pemangkasan batang), sehingga belum begitu produktif.

Sedangkan setelah tahun 2014, permasalahan yang dihadapi petani kopi yaitu musim kemarau panjang.

"Tahun ini bagus (2019), karena banyak batang baru yang menghasilkan buah, bunga, tapi karena kemarau panjang jadi kurang mekar sempurna. Cabang kalo kurang sempurna produksinya ya terpengaruh, pupuk dan perawatan yang mempengaruhi itu. Cuaca apalagi, sangat mempengaruhi itu, ya kalo udah dipupuk tapi nggak hujan ya menguap saja tu pupuknya, nggak ngeresep ke kopinya" penuturan key informant kedua.

Air hujan berperan dalam pencairan pupuk agar dapat diserap dengan baik oleh pohon kopi, untuk mempercepat partumbuhan batang, agar dapat menghasilkan bunga dan buah kopi, namun saat kemarau panjang petani kesulitan, sebab pemberian pupuk lebih banyak menguap dari pada terserap tanah perkebunan kopi, selain itu saat musim kemarau panjang, bunga kopi tidak dapat mekar secara sempurna. Menurut key informant, musim kemarau saat ini lebih ekstream dibandingkan dengan musim kemarau pada tahun-tahun lalu, hal ini mempengaruhi hasil pemupukan.

"Kurang, kan begitu kering, sekali hujan 1-2 kali masih belum berani pemupukan, nunggu tanahnya, biar nggak kekeringan dulu tanahnya, ya percuma dipupuk kalo cuma nguap aja pupuknya. Hujan dulu sama 
hujannya sekarang beda. Misal dulu hujan seminggu cukup sekarang kurang, la airnya meresep ditanah yg kering gitu. Panasnya beda mbak".

Sedangkan menurut key informant ketiga, bukan hanya cuaca yang mempengaruhi hasil perkebunan kopi, jarak antar pohon kopi juga dapat mempengaruhi, karena jarak pohon kopi yang di perhutani lebih luas dan hasil produksinya lebih bagus dan banyak, sedangkan perkebunan kopi PT jaraknya terlalu mepet sehingga mempengaruhi penerimaan penyinaran panas matahari.

Seluruh key informant melakukan petik merah (kucuali pada lahan perhutani milik key informant ketiga), pemetikan petik merah dipilih petani karena kualitas yang lebih baik dan harga yang lebih tinggi, begitupun dengan pengupasan, petik merah mempermudah proses pengupasan, kopi merah lebih mudah mengelupas dibandingkan kopi hijau. Hal tersebut didukung dengan penelitian Universitas Diponegoro (2013) yang juga menyatakan bahwa masih terdapat permasalahan pada pemetikan/ pemanenan buah kopi karena teknik pemanenan kopi yang dilakukan masih rendah sehingga belum memenuhi standar kualitas karena sebagian petani masih melakukan petik hijau.

Menurut Rosiana et al., (2018); Budihardjo dan Fahmi (2020); (Kasutjianingati et al., 2020) pengolahan pasca panen kopi mempengaruhi produksi kopi robusta. Dari segi kualitas produk kopi, cara panen yang lebih disarankan yaitu panen merah (8-11 bulan sejak dari kuncup hingga masak penuh) (Pusat Penelitian dan Pengembangan Perkebunan, 2010).

Kopi hasil panen merah menghasilkan biji yang lebih berat dengan bentuk yang lebih besar dan sempurna, rasa lebih enak, tahan lama apabila disimpan di gudang, harga jual lebih tinggi dan banyak diminati oleh perusahaan kopi.

Meskipun sudah ada petani yang sudah mengolahnya hingga menjadi kopi bubuk (petik merah), namun karena berbagai alasan, masih terdapat petani kopi yang hanya memanen buah kopi yang masih berwarna kuning bahkan hijau, dan hanya mengolah hingga kopi OSE (petik hijau) (Pratiwi, 2016).

Menurut key informant ketiga, alasan memilih sistem panen petik hijau pada lahan perhutaninya karena untuk mempercepat sistem penjualan kopi, untuk dapat segera menerima pendapatan hasil panen. Sedangkan menurut penelitian yang dilakukan oleh Ismawan dan Zainuddin (2013) terkadang petani kopi menjual dalam bentuk buah kopi yang telah kering (kopi asalan), karena tidak adanya perbedaan harga yang signifikan di tingkat petani, perbedaan harga di tingkat desa yang hanya Rp 1.000,00- per liter untuk jenis kopi robusta dan bahkan tidak ada perbedaan harga untuk jenis arabika, baik secara panen hijau maupun panen merah, menyebabkan petani lebih memilih untuk melakukan panen hijau.

Selain selisih harga yang dianggap tidak menguntungkan, faktor-faktor lain penyebab petik hijau yaitu keterbatasan pengetahuan tentang teknik pemanenan kopi yang baik (Pratiwi, 2016), tuntutan kebutuhan ekonomi, (Pamungkas et al., 2019), perilaku pedagang atau eksportir yang tidak memberiakan insentif harga atas biji kopi yang panen masak sehingga petani enggan melakukan panen tepat waktu dan grading (Mayrowani, 2013), dan cara panen yang dilakukan oleh petani rakyat tidak dapat dirubah karena sudah menjadi kebiasaan para petani kopi rakyat (Sativa et al., 2014). Menurut Ramanda et al., (2016), apabila mutu biji kopi yang dihasilkan petani masih tergolong biji kopi asalan (belum ada penggolongan pada tingkat petani) maka akan berakibat pada rendahnya harga jual kopi.

Berdasarkan hasil penelitian, terdapat jasa pengupasan biji kopi keliling di Kecamatan Kandangan, biaya penggilingan perkarung yaitu Rp 3.000,00-. Petani biasa menggunakan jasa tersebut. Pengolahan biji kopi menggunakan pulper kopi dapat 
meningkatkan pendapatan petani kopi (Resdianto, 2015).

Setelah menjadi OSE sebagian besar petani menjualnya ke tengkulak, meskipun harga jual kopi di tengkulak lebih rendah dibandingkan dijual secara langsung ke konsumen maupun ke kafe. Harga baik sebelum maupun setelah tahun 2014 berfluktiatif namun setiap peningkatan atau penurunan tidak begitu curam, harga tertinggi apabila dijual ke pemilik kafe dapat mencapai $\mathrm{Rp}$ $28,000.00-/ \mathrm{kg}$ sedangkan apabila dijual ke tengkulak paling tinggi hanya Rp 25,000.00$/ \mathrm{kg}$. Key informant pertama yang juga menjual kopi dalam bentuk kopi bubuk menetapkan harga Rp 70,000.00-/kg pada kopi hasil produksinya. Sedangkan harga kopi OSE dengan metode petik hijau hanya $\mathrm{Rp} 22,000.00-/ \mathrm{kg}$.

Menurut key informant kedua dan ketiga, sistem jual ke tengkulak karena hasil produksi kopi belum memenuhi standar permintaan pasar, pentingnya standar kualitas kopi karena hasil dari olahan kopi dipengaruhi oleh hasil dari panen kopi.

Menurut Hidayatullah et al., (2019) terdapat beberapa aspek permintaan pasar yang tidak terpenuhi, diantaranya aspek produksi, pemasaran, pangsa pasar dan aspek sumber daya manusia. Menurut Indrasari (2020); (Savitry et al., (2020) kurangnya pengetahuan dan informasi petani mengenai kondisi pasar, berakibat posisi tawar petani dalam menentukan harga jual kopi menjadi lemah. Padahal, dengan pertukaran informasi, mampu membentuk pembagian fungsional kerja di sepanjang rantai nilai dan dapat meningkatkan kemampuan dalam mengelola hambatan yang masuk (Permatasari et al., 2018).

Seharusnya petani memiliki kekuatan penawaran yang bagus agar terhindar dari ketergantungan terhadap tengkulak. Ketergantungan tersebut karena kemudahan tengkulak dalam menyediakan uang tunai yang dibutuhkan oleh petani (Novita et al., 2012), juga terdapat hubungan pinjaman modal antara tengkulak dengan petani kecil di pedasaan. Padahal hal tersebut bertujuan agar tengkulak dapat mengikat petani sehingga stok kopi tetap terjaga (Marlina et al., 2017).

Sedangkan menurut Universitas Diponegoro (2013) Struktur industri pengolahan kopi nasional belum proporsional, karena hanya 20\% kopi diolah menjadi kopi olahan (kopi bubuk, kopi instan dan kopi mix), sedangkan $80 \%$ dalam bentuk kopi biji kering (coffee beans).. Dibutuhkan kebijakan pemerintah untuk mempengaruhi produksi kopi (Gathura dan Jomo, 2013) dan perlu menentukan tata kelola yang melibatkan pemangku kepentingan (Ssebunya et al., 2016); (Jácome dan Garrido, 2017).

Rantai industri yang terkait sangat pendek, hanya sebatas industri pengupaasan kopi dan industri kopi bubuk. Saat ini komoditas yang terlibat barulah industri pengupasan kopi, industri kopi bubuk dan trading house, sehingga margin minuman kopi tertinggi hanya dinikmati oleh pelaku trading house kopi. Hal ini karena belum memanfaatkan peluang lain, seperti bisnis saprotan (Universitas Diponegoro, 2013), berbisnis Cold Brew, Pojok Kopi (Coffee Corner) dan Mobil Kopi (Coffee Truck) (Kementrian Perindustrian, 2017) atau juga dapat bekerja sama dalam Pemanfaatan limbah padat kopi sebagai bahan bakar alternatif dalam bentuk briket (Khusna dan Susanto, 2015).

Industri pengolahan kopi masih kurang berkembang disebabkan oleh faktor teknis, sosial dan ekonomi. Menurut penelitian yang dilakukan oleh Oelviani dan Hermawan (2017) kebutuhan teknologi budidaya kopi dan teknologi penangkaran benih mampu mempengaruhi produksi kopi.

Penerapan teknologi pengolahan hasil kopi baru diterapkan oleh sebagain kecil perusahaan industri pengolah kopi, hal ini dikarenakan keterbatasan informasi, modal, teknologi, dan manajemen usaha. Padahal produk industri olahan berpotensi besar dalam memberikan nilai tambah yang tinggi (Lestari et al., 2021). Harga biji kopi Rp16,000 per kilogram, tetapi apabila dijual dalam 
bentuk bubuk dan kemasan, harganya dapat mencapai Rp60,000 - Rp70,000 per kg (Badan Pengawas Perdagangan Berjangka Komoditi, 2015).

Di Pabrik Kopi Banaran kapasitas produksi kopi beras lebih tinggi dari pada kopi bubuk, karena permintaan biji kopi atau kopi beras lebih banyak. Besarnya permintaan biji kopi oleh luar negeri, sedangkan kopi bubuk hanya dalam negeri. Sehingga sebagian besar ekspor yang dilakukan dalam bentuk biji kopi (99.8 persen) dan ekspor kopi dalam bentuk kopi olahan masih dalam persentase yang sangat kecil (Aisyah, 2018). Keadaan seperti ini telah lama terjadi dan masih sulit untuk berubah (Tania, 2018).

Pasar biji kopi Taiwan merupakan pasar terbesar di negara asia setelah jepang, permintaan pasar Taiwan yaitu produk biji kopi dengan varietas unggulan dan memiliki cita rasa khas. Namun sayangnya Taiwan lebih banyak mengimpor biji kopi, karena untuk pencampuran dan pemanggangan biji kopi, Taiwan dapat melakukannya sendiri (Directorate General for National Export Development, 2013).

Sehingga hasil dari analisis Value Chain, faktor-faktor yang mempengaruhi penurunan produksi kopi Robusta di Kabupaten Temanggung diantaranya yaitu usia pohon kopi. Sebagian besar pohon kopi di Kabupaten Temanggung sudah berusia 39 tahun (sudah melewati masa produktif) (Evizal, 2013), petani kopi tetap menggunakan pohon kopi tersebut, karena masih mampu berproduksi.; Faktor penurunan produksi kopi lainnya yaitu jarak antar pohon kopi Robusta. Jarak tersebut bervariasi, dalam satu perkebunan antar pohon ada yang berjarak $1 \times 2$, $2 \times 2$ dan $3 \times 2$, meskipun sudah ada perkebunan yang berjarak $2,5 \times 2,5$. Bervariasinya jarak pohon kopi karena pengetahuan para pendahulu, dengan tujuan memaksimalkan luas kebun dengan jumlah pohon yang banyak. Menurut Menteri Pertanian Republik Indonesia (2017) jarak tanaman kopi Robusta yang baik yaitu berkisar antara $2,5 \times 2,5 \mathrm{~m} ; 2,5 \times 3 \mathrm{~m}$ dan $2,5 \times 2,5 \times 4 \mathrm{~m}$; sedangkan modal tidak menjadi masalah karena petani dapat dengan mudah dalam mengakses modal.; Begitu juga dengan akses pupuk yang tidak menjadi masalah. Akses pupuk baik sebelum maupun setelah tahun 2014 mudah, begitupun dengan harga pupuk yang cukup stabil. Justru menurut key informant akses pupuk semakin mudah, dan pada tahun 2019 harga pupuk turun sebesar Rp.4000,00-/Kw.; Pemilihan metode pemetikan mampu mempengarhui produksi kopi Robusta di Kabupaten Temanggung. Semua key informant memanen dengan pemetikan petik merah, baik sebelum maupun setelah tahun 2014. Namun untuk key informant ketiga, untuk perkebunan yang Perhutani, Ia memilih untuk pemetikan campuran (merah dan hijau) baik sebelum maupun setelah tahun 2014 (perkebunan PT petik merah).; Begitu juga dengan kurangnya ketersediaan jasa pemetikan kopi Robusta yang dinilai mampu mempengaruhi penurunan produksi kopi Robusta di Kabupaten Temanggung. Pemetikan kopi merah harus dilakukan diwaktu yang tepat, petani kopi biasa memanen saat kopi sudah merah $75 \%$ kopi hijau $25 \%$, estimasi ini dirasa paling tepat, dimana sudah banyak biji yang sudah berwarna merah dan harus segera dipanen, tidak bisa dilakukan pemanenan $100 \%$ biji merah, sebab buah kopi tidak dapat masak serentak. Sehingga dibutuhkan jasa pemetikan untuk dapat memaksimalkan hasil perkebunan kopi; Masih banyak petani yang langsung menjual kopi (dalam bentuk OSE) ke tengkulak, hal tersebut menjadi masalah karena belum memaksimalkan potensi penjualan hasil produksi kopi, mengingat pendapatan dari penjualan produksi kopi mempengaruhi modal dalam berkebun pada periode selanjunya. Perlu adanya transformasi metode pertanian tradisionalis (hanya fokus panen buah kopi), menjadi petani modern (berbasis pada aktivitas industri) (Zakki, 2020). 


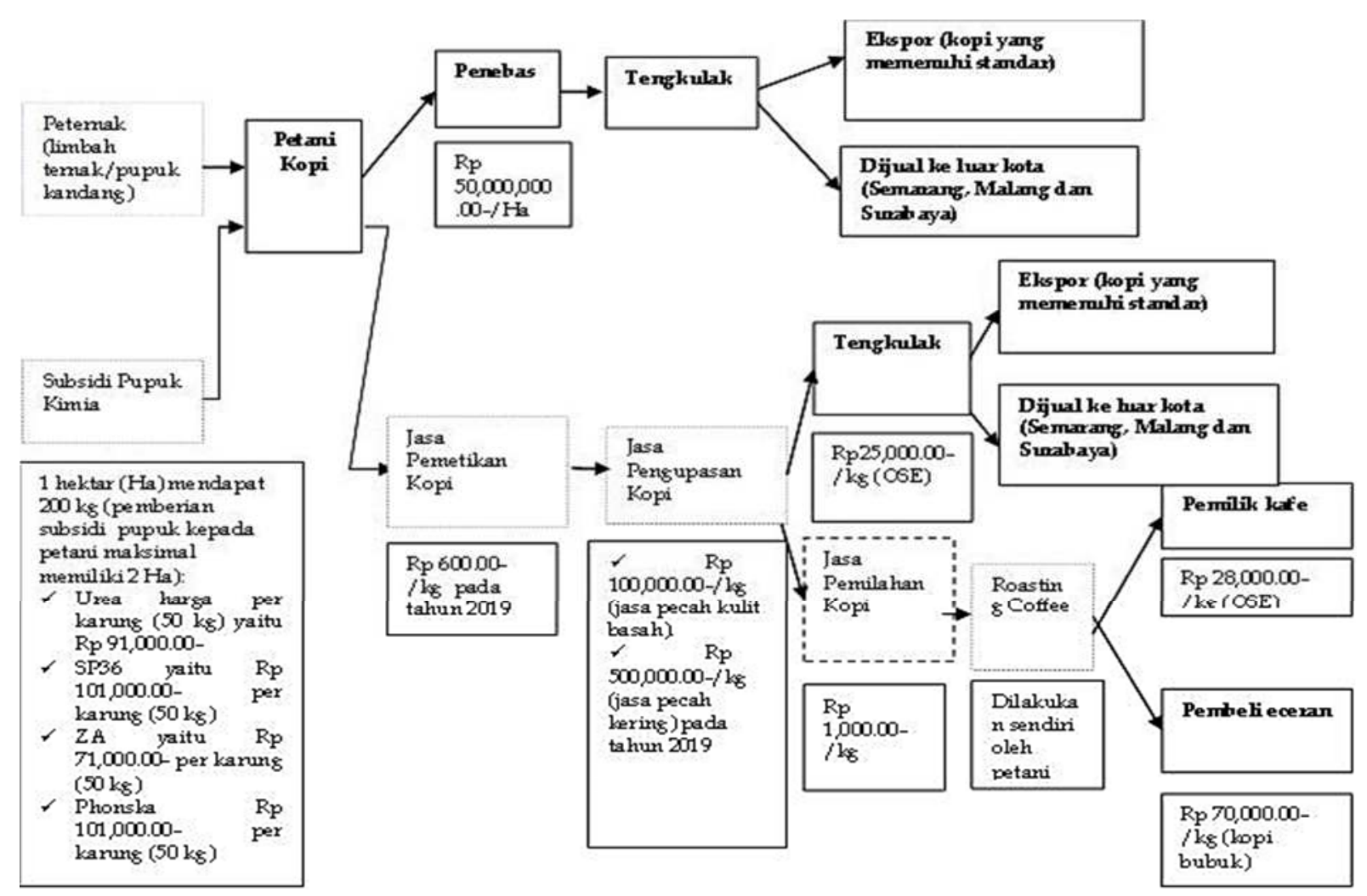

Gambar 3

Value Chain Kopi Robusta Kabupaten Temanggung pada Tahun 2019

Sumber: Hasil wawancara, diolah penulis (2019)

\section{Hasil Analisis dan Pembahasan Backward dan Forward Linkage}

Dalam berkebun kopi, pupuk kandang merupakan hal penting untuk menyuburkan tanaman kopi, peran pupuk kandang juga dapat digunakan untuk mengurangi ketergantungan akan penggunaan pupuk kimia. Menurut Prasmatiwi et al., (2017) pengurangan penggunaan pupuk kimia dengan diimbangi penggunaan pupuk kandang tidak mengurangi produksi, dengan demikian dengan adanya penyedia pupuk kandang dapat membantu dalam upaya meminimalisasi penggunaan pupuk kimia. Apabila petani kopi tidak memiliki ternak, maka hubungan antara petani kopi dengan peternak juga dapat terjalin, dimana rumput yang ada di perkebunan kopi dapat digunakan untuk pakan ternak (kambing, domba ataupun sapi) dan petani mendapatkan limbah ternah untuk pupuk kandang, seperti yang dilakuakan oleh key informant pertama, yang membeli pupuk kandang untuk pemupukan di kebun kopinya. Menurut Kiying dan Gwali (2012) petani yang menyediakan pupuk kandang sendiri daripada membeli akan lebih untung.

Dalam perawatan kopi, dilakukan pemangkasan terhadap batang yang terkena penyakit, dalam hal ini petani biasa mengerjakannya sendiri tanpa bantuan buruh tani (untuk kehati-hatian kualitas batang), buruh tani hanya dibutuhkan saat pemetikan, hal tersebut karena buah kopi harus segera dipanen saat sudah merah, jika terlalu lama dan tidak segera dipanen, buah kopi akan jatuh ke tanah dan hal tersebut akan mengurangi mutu, sehingga dibutuhkan jasa pemetik kopi untuk menjaga kualitas biji kopi yang dipanen, namun saat ini ketersediaan jasa pemetik kopi tidak semudah tahuntahun lalu (sebelum 2014), sebab warga lebih memilih merantau, sehingga untuk mendapatkan jasa pemetik kopi, petani kopi harus 
mencari jasa pemetik kopi dari desa lain. Biaya jasa pemetikan kopi tahun 2019 yaitu Rp 600.00-/ kg sedangkan pada tahun 2018 hanya Rp 500.00-/ kg. Hal tersebut selaras dengan penelitian yang dilakukan oleh Syahrial et al., (2017); Junaidi dan Hidayat, (2017) bahwa tenaga kerja dapat mempengaruhi produksi kopi.

Hasil dari penelitian penulis justru berbanding terbalik dari penelitian yang dilakukan oleh (Jumiati dan Mulyani, 2014), yang menyatakan bahwa penggunaan tenaga kerja yang justru dapat mengurangi hasil produksi kopi karena berlebihan proporsinya.

Untuk mengolah kopi hasil panen, di Temanggung terdapat jasa pengupasan kulit kopi keliling, upah pecah kulit basah dengan biaya $\mathrm{Rp}$ 100,000.00-/ kg sedangkan untuk jasa pecah kering $\operatorname{Rp} 500,000.00-/ \mathrm{kg}$, petani biasa menggunakan jasa tersebut untuk mendukung proses paska panen, hal tersebut dipilih petani kopi dari pada harus menjual hasil kopi dengan sistem tebas. Sistem tebas yaitu sistem penjualan kopi, dimana penebas membayar uang muka, pelunasan dilakukan setelah buah kopi dipanen, setelah disepakati penjualan dengan penebas, maka pemanenan sepenuhnya menjadi tanggung jawab penebas, petani hanya mendapatkan uang bersih saja. Petani yang memilih memanen sendiri dari pada sistem tebas, dengan alasan untuk menjaga kualitas kopi yang dihasilkan (pemanenan dilakukan disaat yang dianggap paling tepat, buah kopi merah) dan untuk menjaga kualitas batang paska panen.

Petani biasa menjual ke tengkulak saat kopi sudah diproses menjadi OSE, hal tersebut merupakan sistem penjualan yang sudah dilakukan petani secara bertahuntahun dan turun-temurun. Hanya key informant pertama yang menjual hasil kopi ke pemilik kafe maupun langsung ke konsumen, sistem ini dirasa lebih menguntungkan, sebab harga yang ditetapkan lebih tinggi daripada harga yang ditetapkan oleh tengkulak. Key informant pertama memilih sistem jual $80 \%$ OSE, dalam bentuk kopi bubuk $15 \%$ dan dalam bentuk roasben 5\% sejak tahun 2016, saat ini penjualan key informant pertama sudah keluar kota, sepeti Salatiga, Jakarta, Jogjakarta, Semarang dan Solo. Terdapat peluang mengolah kopi hingga menjadi bubuk kopi, karena permintaan kopi bubuk cukup tinggi (Ariyanti et al., 2019).

Untuk menjaga kualitas kopi, dilakukan proses pemilahan kopi, baik sebelum maupun setelah pengupasan kulit, key informant pertama memiliki pekerja pemilahan kopi OSE dirumahnya, namun untuk pemanggangan dilakukan sendiri dirumahnya tanpa bantuan pekerja.

Hasil dari produksi kopi yang langsung dijual ke tengkulak dinilai belum memaksimalkan peluang/nilai jual, karena pendapatan yang diperoleh lebih rendah disbandingkan apabila kopi dijual hingga ke pemilik kafe ataupun apabila diolah hingga menjadi kopi bubuk yang langsung dijual secara langsung ke konsumen.

"Saya menjual kopi ke tengkulak karena olahan kopi saya secara manual/tradisional sedangkan kalau jual ke kafe atau exportir itu perlu pengolahan khusus sedangkan petani seperti saya ini bagaimana mudahnya saja" penuturan dari key informant kedua

Hal tersebut selaras dengan latar belakang sistem jual yang dipilih oleh key informant ketiga yang menyampaikan bahwa alasan menjual ke tengkulak karena sistem pengelolaan yang dilakukannya belum sesuai dengan permintaan/belum memenuhi standar. Menurut Tuningrat et al., (2019); Wiguna et al., (2019) solusi agar petani kopi dapat mengembangkan dan meningkatkan kapasitasnya untuk mengakses pasar kopi premium yaitu dengan cara mengembangkan segmentasi permintaan kopi melalui skema relasi kopi. Peningkatan pangsa pasar juga dapat dicapai dengan peningkatan teknologi, kualitas dan produktivitas kopi (Rosiana et al., 2017).

Pemaksimalan peluang bertujuan untuk dapat meningkatan pendapatan, hal tersebut dapat meningkatkan saving guna memperluas lahan perkebunan kopi dan meningkat- 
kan juga keputusan untuk melakukan penebangan guna pembaharuan pohon kopi dengan bibit yang lebih unggul, mengingat usia pohon kopi yang sudah melewati usia produktif.

Dengan penebahan/pembaharuan pohon kopi dibutuhkan waktu 3-4 tahun untuk dapat dipanen (Soliman et al., 2019). Karena dengan pembaharuan pohon kopi baru dengan bibit yang lebih unggul akan meningkatkan produktivitas, sehingga produksi kopi dan keuntungan petani juga akan meningkat (Erdiansyah dan Sumirat, 2014).

Sehingga hasil dari analisis Backward Linkage, fator-faktor yang dapat menurunkan produksi kopi Robusta yaitu pengguaan input yang masih menggunakan pohon kopi warisan sejak tahun 1980-an. Sedangkan permasalahan pada Forward Linkage yaitu sebelum tahun 2014 seluruh kopi milik key informant pertama, kedua dan ketiga yang sudah diolah menjadi OSE (kopi siap sagrai) semua dijual ke tengkulak, namun setelah tahun 2014, hanya key informant pertama yang menjualnya secara mandiri baik dijual langsung kekonsumen maupun ke kafe (mulai sekitar 2016), namun key informant kedua dan ketiga tetap menjualnya ke tengkulak, sistem penjualan tersebut menjadi permasalahan karena tidak memaksimalkan hasil penjualan, sehingga dapat mempengaruhi modal pengelolaan perkebunan periode selanjutnya.

\section{Hasil Analisis dan Pembahasan Diagram Fishbone}

Berdasarkan hasil penelitian, cuaca menjadi masalah utama penurunan produksi kopi Robusta Kabupaten Temanggung.

“Dulu pernah musim penghujan berkepanjangan tahun 2013an, itu tidak ada tumbuh muda, bunganya pada busuk kan jadinya gugur. Paling bagus ya tahun 2014 itu bagus, musimnya bagus, gak kekeringan panjang dan gak penghujan panjang. Kalo musim kemarau atau penghujan berkepanjangan sama-sama merugikan. Tapi ya saya sebagai ketua tani sering menekankan, mau seperti apa, mau harga kek gimana, naik atau turun ya diusahakan maksimal, biar produksinya tinggi, ya syukur-syukur ada peningkatan kualitas. Kalo produksinya tinggi kan ya untung, mau perawatannya sebaik apa tapi kalo musimnya buruk ya sama saja berkurang, tapi ya kalo musimnya bagus tapi perawatannya asal, gak di pupuk gak dirawat bagus, ya hasilnya sedikit". Penuturan dari key informant pertama.

Cuaca memegang peran yang penting dalam budidaya perkebunan kopi Robusta, masyarakat yang menjaga produktivitas pohon kopi dengan melakukan pemangkasan batang untuk Menumbuhkan batang muda yang lebih produktif.

“Tahun 2018 produksi saya turun. Itu karena batang mba, jadi setelah panen harus pemangkasan batang, biar tumbuh batang baru yang lebih produktif, cabang yang sudah tua gitu kan harus dipotong. Nanti harus nunggu sampe bisa berbuah, la itu makanya produksinya beda dari tahun lalu, biasanya ya gitu, setahun banyak, setahun berkurang, gitu. 2018 menunggu hujan, karena batang akan cepat tumbuh kalo ada hujan". Hal tersebut disampaikan oleh key informant ketiga.

Tanpa adanya cuaca yang baik maka pertumbuhan batang tidak dapat optimal. Petani juga melakukan pemupukan 2 (dua) kali yaitu pada awal dan akhir musim hujan, agar pupuk dapat menyerap dengan baik ke tanah, dibutuhkan air yang cukup. Apabila terjadi kemarau panjang seperti yang terjadi pada tahun 2019 maka pemupukan juga akan terganggu, begitupun juga dengan pertumbuhan bunga yang tidak dapat mekar sempurna karena panas yang terlalu menyengat dan kurang air. Dengan kekeringan, maka pupuk tidak dapat bekerja dengan baik, batang tidak dapat tumbuh sempurna dan bunga tidak dapat mekar sempurna, hal ini dapat menurunkan produksi biji kopi. Sehingga dengan cuaca hujan dan kemarau yang berkepanjangan dapat berakibat pada penurunan produksi kopi.

Hal tersebut selaras dengan hasil penelitian (Tri et al., 2015); (Astuti et al., 2020) 
yang menyatakan bahwa kondisi cuaca dan iklim yang tidak menentu mampu mempengaruhi produksi kopi, meningkatkan insiden, mengancam kelangsungan budidaya kopi (Andrade et al., 2012); (Partelli et al., 2013); (Poltronieri dan Rossi, 2016); (Bongase dan Jimma, 2017) dan mengancam mata pencaharian di banyak negara penghasil kopi (Krishnan dan Gardens, 2017), karena menyebabkan fluktuasi suhu, curah hujan, kelembaban, nutrisi tanah, kelembaban, sinar matahari, abrasi dan suhu tanah, sehingga mempengaruhi pertumbuhan dan produktivitas tanaman kopi (Aritonang, 2018); (Erfandari et al., 2019); (Gokavi dan Kishor, 2020); (Hidayah et al., 2019). Sehingga kondisi iklim memiliki peran besar dalam produksi kopi (Indzere et al., 2018); (Kath et al., 2021).

\section{SIMPULAN DAN SARAN \\ Simpulan}

Hasil dari pengkombinasikan ketiga alat analisis menghasilkan temuan mengenai faktor-faktor yang dapat mempengaruhi penurunan produksi kopi Robusta di Kabupaten Temanggung, dari metode analisis Value Chain, yaitu usia pohon kopi (melebihi usia produktif), jarak pohon kopi (tidak sesuai dengan ketententuan dari Kementerian Pertanian), kurangnya jasa pemetik kopi (sebagian besar penyedia jasa pemetik kopi memilih untuk merantau dan beralih profesi), dan terlalu singkatnya Value Chain (sistem penjualan hasil produksi kopi langsung di jual ke pengepul). Sedangkan hasil dari analisis Backward dan Forward Linkage menghasilkan pernyataan bahwa penurunan produksi kopi terjadi karena penggunaan input berupa pohon kopi yang masih turun temurun dari periode tahun 1980-an dan kurangnya kerjasama dengan sektor-sektor lain, seperti sektor perdagangan dan sektor industri. Sedangkan hasil penelitian dengan metode analisis Diagram Fishbone yaitu cuaca menjadi faktor utama penyebab penurunan produksi kopi di Kabupaten Temanggung terdapat dalam gambar 4.

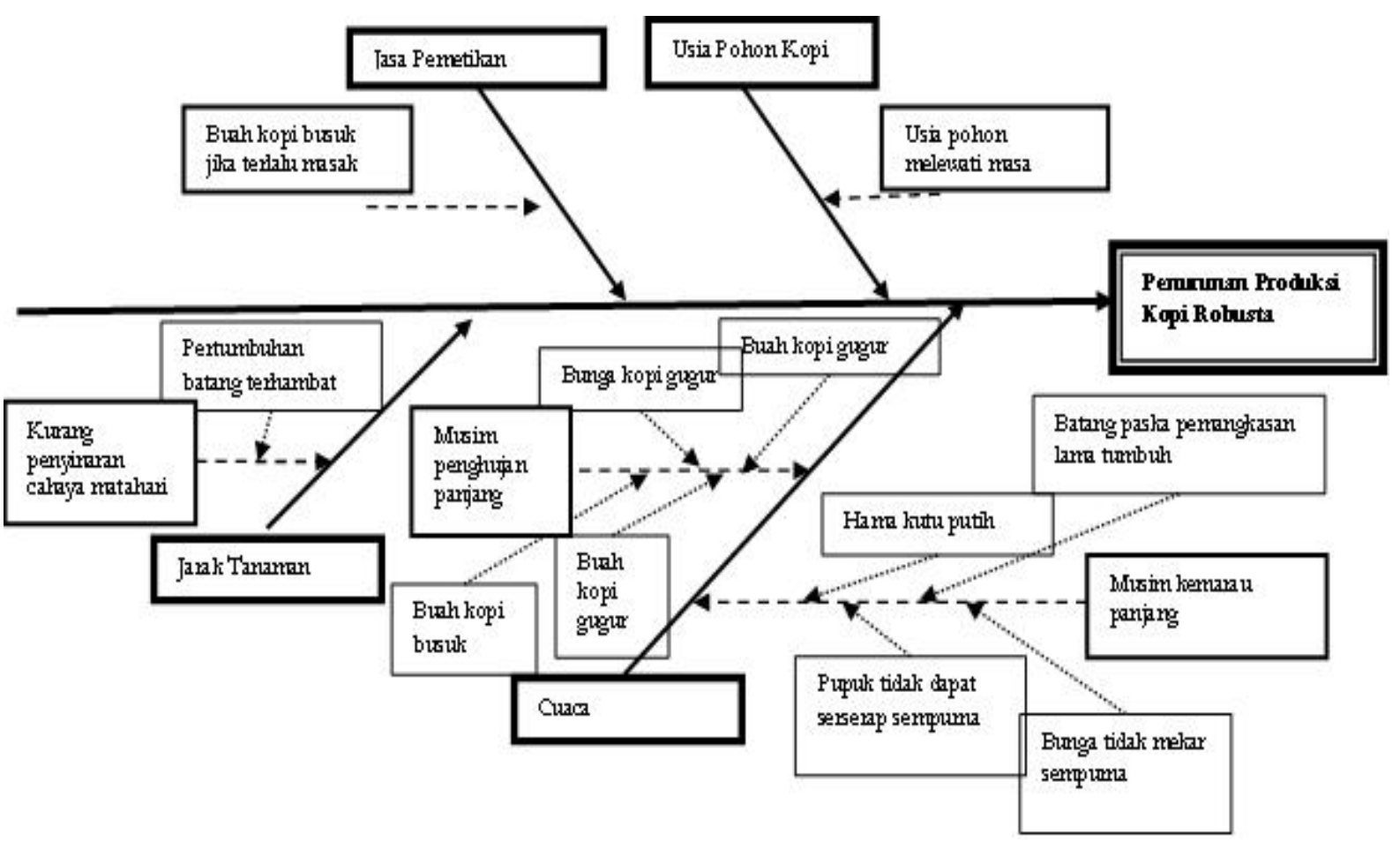

Gambar 4

Diagram Fishbone Penurunan Produksi Kopi Robusta di Kabupaten Temanggung Sumber: Hasil wawancara, diolah penulis (2019) 


\section{Saran}

Berdasarkan penelitian ini, implikasi untuk petani kopi Robusta di Kabupaten Temanggung yaitu dibutuhkan peremajaan pohon kopi dengan melakukan penebangan dan penanaman pohon kopi baru (new planting) dengan varietas yang lebih unggul, dalam hal ini dibutuhkan sosialisasi dari pemerintah daerah agar petani mau untuk melakukan new planting dan menggunakan varietas yang lebih unggul serta mendorong petani untuk mengaplikasikan Peraturan Menteri Pertanian Nomor 49/Permentan/ Ot.140/4/2014. Sosialisasi bertujuan meyakinkan petani kopi, sebab dengan new planting produksi kopi akan menurun tajam dalam jangka pendek (2,5-3 tahun) dan akan meningkat tajam setelahnya (jangka panjang). Pemetikan kopi lebih baik menggunakan metode petik merah untuk memaksimalkan kualitas dan mampu memenuhi standar permintaan pasar, sedangkan untuk ketersediaan jasa pemetik kopi, diperlukan kerjasama dengan beberapa kelompok tani dari desa lain dan dapat juga menggunakan mesin pemanen kopi.

Namun karena penelitian ini merupakan studi kasus, sehingga kesimpulan dalam penelitian ini tidak akan digunakan untuk kepentingan generalisasi.

\section{DAFTAR PUSTAKA}

Abimanyu, W., S. Hadi, dan A. A. Ridho. 2018. Studi Komparatif Usaha Perkebunan Kopi Robusta dan Kopi Arabika di Kecamatan Panti Kabupaten Jember. Jurnal Agribest 2(1): 14-23.

Aisyah, N. S. 2018. Analisis Nilai Tambah Industri Pengolahan Buah Cherry Kopi (Kasus di Mahkota Java Coffee Garut). Skripsi. Departemen Agribisnis Institut Pertanian Bogor. Bogor.

Aklimawati, L., Yusianto, dan S. Mawardi. 2014. Characteristics of Quality Profile and Agribusiness of Robusta Coffee in Tambora Mountainside, Sumbawa. Pelita Perkebunan 30(2): 159-180.

Andrade, G. A., W. Da Silva Ricce, P. H. Caramori, G. C. Zaro, dan C. De Conti
Medina. 2012. Agroclimatic Zoning of Robusta Coffee in the State of Paraná and Impacts of Climate Change. Semina: Ciencias Agrarias 33(4): 1381-1390.

Andriani, D. R., H. Santoso, dan R. W. Tama. 2012. Production and Profit Analysis of Robusta Coffee Export Quality (Case Study at PT Perkebunan Nusantara XII (Persero) Ngrangkah Pawon Plantation, Kediri Regency. Agricultural SocioEconomics Journal 12(3): 209-212.

Anggita, D., Soetriono, dan A. Kusmiati. 2018. Analisis Faktor Produksi dan Strategi Pengembangan Usahatani Kopi Rakyat di Desa Gombengsari Kecamatan Kalipuro Kabupaten Banyuwangi. Jurnal Ilmu-Ilmu Pertanian AGRIKA 12(2): 118-132.

Aritonang, B. 2018. Faktor Pendorong dan Penghambat Pertanian Kopi di Desa Aekraja Kecamatan Parmonangan. Tesis. Fakultas Ilmu Sosial dan Ilmu Politik Universitas Sumatera Utara. Medan.

Ariyanti, W., A. Suryantini, dan Jamhari. 2019. Usaha Tani Kopi Robusta di Kabupaten Tanggamus: Kajian Strategi Pengembangan Agrobisnis. Jurnal Kawistara 9(2): 179-191.

Ardiansah, M. R., A. Widjajanti, dan A. Jumiati. 2014. Analisis Faktor yang Mempengaruhi Produksi Usahatani Kopi Rakyat di Kecamatan Silo Kabupaten Jember. Universitas Jember Repository: 1-6.

Astuti, Y. T. M., T. N. B. Santosa, D. P. Putra, E. Rahayu, A. Solifudin, dan G. H. Nugraha. 2020. Karakteristik Vegetatif dan Taksasi Produksi Kopi Robusta Tahun 2018 dan 2019 (Survey pada Perkebunan Kopi Rakyat di Dusun Mandang, Desa Sucen, Kecamatan Gemawang, Kabupaten Temanggung). AGROMIX Jurnal Ilmiah Fakultas Pertanian, Universitas Yudharta Pasuruan 11(2): 125-135.

Azmi, R. dan A. Handriatni. 2018. Effect of Substance Types of Natural Growth Regulators on Growth of Some Robusta Coffee Clones Cuttings (Coffea 
canephora). Biofarm: Jurnal Ilmiah Pertanian 14(2): 71-81.

Badan Pengawas Perdagangan Berjangka Komoditi. 2015. Analisis harga kopi Robusta pekan ketiga Juni 2015. Prosiding Badan Pengawas Perdagangan Berjangka Komoditi: 1-2.

Badan Pusat Statistik. 2018a. Kecamatan Kandangan Dalam Angka 2018. Prosiding Badan Pusat Statistik Kabupaten Temanggung: 1-61.

Badan Pusat Statistik. 2018b. Statistik Kopi Indonesia 2017. Prosiding Direktorat Statistik Tanaman Perkebunan: 17-69. ISBN 978-602-438-187-5.

Biro Humas Kemenperin, dan Tim Komunikasi Pemerintah Kemkominfo. 2017. Rayakan Hari Kopi, Kemenperin Terus Tingkatkan Ekspor Kopi Nasional. Prosiding Kementerian Komunikasi dan Informatika Republik Indonesia.

Bongase, E. D. dan Jimma. 2017. Impacts of Climate Change on Global Coffee Production Industry: Review. African Journal of Agricultural Research 12(19): 1607-1611.

Budi, L. Sihombing, dan Salmiah. 2016. Analisis Sistem Agribisnis Kopi Arabika (Coffea Arabica) di Desa Paraduan, Kecamatan Ronggur Nihuta, Kabupaten Samosir. Journal on Social Economic of Agriculture and Agribusiness: 1-14.

Budihardjo, K. dan W. M. Fahmi. 2020. Strategi Peningkatan Produksi Kopi Robusta (Coffea L.) di Desa Pentin-gsari, Kecamatan Cangkringan, Kabupaten Sleman, Daerah Istimewa Yogyakarta. Jurnal Imliah Mahasiswa Agroinfo Galuh 7(2): 373-379.

Byrareddy, V., L. Kouadio, S. Mushtaq, dan R. Stone. 2019. Sustainable Production of Robusta Coffee under a Changing Climate: A 10-Year Monitoring of Fertilizer Management in Coffee Farms in Vietnam and Indonesia. Agronomy 9(9): 1-19.

Chandra, D., R. H. Ismono, dan E. Kasymir. 2013. Prospek Perdagangan Kopi Robusta Indonesia di Pasar Internasional.
Jurnal Ilmu Ilmu Agribisnis 1(1): 10-15.

Dahang, D. dan K. P. S. M. Munthe. 2020. Pengaruh Teknik Budidaya Terhadap Produksi Kopi (Coffea Spp. L.) Masyarakat Karo. Jurnal Agroteknosains 4(2): 47-62.

Directorate General for National Export Development. 2013. Market Intelligence - KDEI Taiwan Peluang Ekspor Biji Kopi ke Pasar Taiwan. Prosiding Kemendag: 183.

Direktorat Jenderal Perkebunan. 2015. Statistik Perkebunan Indonesia 2014-2016 Kopi. Repositori Kementerian Pertanian: 1-97.

Erdiansyah, N. P. dan U. Sumirat. 2014. Keragaman Potensi Daya Hasil Populasi Bastar Kopi Robusta (Coffea Canephora). Pelita Perkebunan 30(2): 92-99.

Erfandari, O., Hamdani, dan D. Supriyatdi. 2019. Keragaman Intensitas Serangan Hama Penggerek Buah Kopi (Hypothenemus Hampei Ferrari) Pada Beberapa Sentra Produksi Kopi Robusta Provinsi Lampung. Jurnal Penelitin Pertanian Terapan 19(3): 244-249.

Evizal, R. 2013. Etno-agronomi Pengelolaan Perkebunan Kopi di Sumberjaya Kabupaten Lampung Barat. Jurnal Agrotrop: Journal of Agriculture Science 3(2): 1-12.

Fatma, Z. 2011. Analisis Fungsi Produksi dan Efisiensi Usaha Tani Kopi Rakyat di Aceh Tengah. Tesis. Program Pacasarjana Institut Pertanian Bogor. Bogor.

Fitriani, B. Arifin, W. A. Zakaria, R. H. Ismono, dan F. E. Prasmatiwi. 2020. Sustainable Production of Lampung Robusta Coffee: A Cost-Benefit Analysis. International Journal of Ecology and Development 35(1): 45-58.

Gathura, M. N. dan Jomo. 2013. Factors affecting Small-Scale Coffee Production in Githunguri District, Kenya. International Journal of Academic Research in Business and Social Sciences 3(9): 132-149.

Ghini, R., W. Bettiol, dan E. Hamada. 2011. Diseases in Tropical and Plantation 
Crops as Affected by Climate Changes: Current Knowledge and Perspectives. Plant Pathology 60(1): 122-132.

Gokavi, N. dan M. Kishor. 2020. Impact of Climate Change on Coffee Production: an Overview. Journal of Pharmacognosy and Phytochemistry 9(3): 1850-1858.

Gumilang, G. S. 2016. Metode Penelitian Kualitatif dalam Bidang Bimbingan dan Konseling. Jurnal Fokus Konseling 2(2): 144-159.

Gumulya, D. dan I. S. Helmi. 2017. Kajian Budaya Minum Kopi Indonesia. Dimensi 13(2): 153-172.

Hidayah, S., Nofialdi, dan Ifdal. 2019. Analisis Risiko Produksi Kopi Robusta di Jorong Pincuran Tujuah, Nagari Batipuh Baruah, Kecamatan Batipuh, Kabupaten Tanah Datar. JOSETA: Journal of Socio-Economics on Tropical Agriculture 1(2): 89-98.

Hidayatullah, S., I. Windhyastiti, E. Aristanto, dan I. K. Rachmawati. 2019. PKM Kopi Rakyat Kelompok Wanita Tani (KWT) "Ngudi Rahayu" Desa Kebobang Wonosari Kabupaten Malang. (JAPI) Jurnal Akses Pengabdian Indonesia 4(2): 130-136.

Haryoko, M., Karno, dan A. Setiadi. 2018. Analisis Faktor yang Mempengaruhi Produksi Kopi Robusta di Kabupaten Temanggung (Studi Kasus di Kecamatan Pringsurat). Jurnal AGROMEDIA 36(2): 46-54.

Hasibuan, Z. A. 2014. Analisis Faktor-Faktor yang Mempengaruhi Produksi dan Pendapatan Petani Kopi di Kabupaten Simalungun. Tesis. Universitas Medan Area. Medan.

Huda, R. B. 2019. Analisis Total Productive Maintenance dengan Metode Overall Equipment Effectiveness Pada Mesin Unigrator di PG Semboro. Skripsi. Teknik Mesin. Universitas Jember. Jember.

Indrasari, Y. 2020. Efesiensi Saluran Distribusi Pemasaran Kopi Rakyat di Desa Gending Waluh Kecamatansempol (Ijen) Bondowoso. Jurnal Manajemen
Pemasaran 14(1): 44-50.

Indzere, Z., Z. Khabdullina, A. Khabdullin, dan D. Blumberga. 2018. The Benchmarking of Chicory Coffee's Production. Elsevier 147: 631-635.

Ismawan, I. N. dan S. Zainuddin. 2013. Panen Hijau: Kebiasaan Lama Petani Kopi di Kabupaten Bantaeng, Sulawesi Selatan yang Perlu Diperbaiki. World Argoforestry Centre (ICRAF) Indonesia 6(3): 3-7.

Isyariansyah, M. D., D. Sumarjono, dan K. Budiraharjo. 2018. Analisis FaktorFaktor Produksi yang Mempengaruhi Kopi Robusta di Kecamatan Sumowono Kabupaten Semarang. Jurnal Sosial Ekonomi Pertanian 2(1): 31-38.

Jácome, A. R. dan A. Garrido. 2017. A Real Option Analysis Applied to the Production of Arabica and Robusta Coffee in Ecuador. Spanish Journal of Agricultural Research, 15(1): 1-12.

Jumiati, E. dan S. I. Mulyani. 2014. Efisiensi Teknis Usahatani Kopi di Kabupaten Tana Tidung (KTT). Agrifor: Jurnal Ilmu Pertanian Dan Kehutanan XIII(2): 155164.

Junaidi, A. dan W. Hidayat. 2017. Analisis Produksi Kopi di Desa Bocek Kecamatan Karangploso Kabupaten Malang. Jurnal Ilmu Ekonomi University of Muhammadiyah Malang 1(1): 92-106.

Kahpi, A. 2017. Budidaya dan Produksi Kopi di Sulawesi Bagian Selatan Pada Abad Ke-19. Lensa Budaya 12(1): 13-26.

Kasutjianingati, A. Wahyono, A. Brilliantina, dan E. K. Novitasari. 2020. SWOT and Analytical Network Process (ANP) Analysis for Robusta Coffee Bean Development Strategy in Panti District, Jember Regency. IOP Conference Series: Earth and Environmental Science 411: 1-7.

Kath, J., V. M. Byrareddy, dan S. Mushtaq. 2021. Temperature and Rainfall Impacts on Robusta Coffee Bean Characteristics. Elsevier 32: 1-15.

Kementerian Koordinator Bidang Perekonomian Republik Indonesia. 2018. Pemerintah Tingkatkan Peran Komoditas 
Kopi Nasional Untuk Bersaing Dalam Persaingan Global. Prosiding Kementerian Koordinator Bidang Perekonomian Republik Indonesia: 1-2.

Kementrian Perindustrian. 2017. Peluang Usaha IKM Kopi. Prosiding Kementerian Perindustrian Republik Indonesia: 1-117.

Khusna, D. dan Susanto, J. 2015. Pemanfaatan Limbah Padat Kopi Sebagai Bahan Bakar Alternatif Dalam Bentuk Briket Berbasis Biomass (Studi Kasus di PT. Santos Jaya Abadi Instan Coffee). Prosiding Seminar Nasional Sains dan Teknologi Terapan III 2015, Institut Teknologi Adhi Tama Surabaya: 247-260.

Kiying, I. dan S. Gwali. 2012. Productivity and Profitability of Robusta Coffee Agroforestry Systems in Central Uganda. Uganda Journal of Agricultural Sciences 13(1): 85-93.

Krishnan, S. dan D. B. Gardens. 2017. Sustainable Coffee Production. Oxford Research Encyclopedias, Environmental Science: 1-19.

Kristian, I. 2019. Upaya Penurunan Idle Pada Proses Produksi PT X Menggunakan Metode Fishbone Diagram. Jurnal Titra 7(2): 145-152.

Läderach, P., J. Ramirez-Villegas, C. Navarro-Racines, C. Zelaya, A. Martinez-Valle, dan A. Jarvis. 2017. Climate Change Adaptation of Coffee Production in Space and Time. Climatic Change 141: 47-62.

Leonard, D. J. dan C. Needham. 2020. Strategies Hospital Manager Use to Improve Customer Services. Open Journal of Business and Management 08(02): 820-854.

Lestari, F., Maryadi, dan D. Adriani. 2021. Analisis Nilai Tambah Aneka Olahan Bubuk Kopi Robusta Berbasis Industri Rumah Tangga (Kecamatan Pagaralam Utara, Kota Pagaralam). Jurnal Paradigma Agribisnis 3(2): 56-70.

Mahfud, M. C. 2012. Teknologi dan Strategi Pengendalian Penyakit Karat Daun untuk Meningkatkan Produksi Kopi Nasional. Jurnal Pengembangan Inovasi
Pertanian 5(1): 44-57.

Malik, A., D. S. Nurchaini, dan R. Herdiyansyah. 2019. Analisa Pengaruh Penggunaan Faktor Produksi terhadap Efisiensi Usahatani Serta Produksipadi Sawah di Kabupaten Batanghari Provinsi Jambi. Prosidding Seminar Nasional Fakultas Pertanian Universitas Jambi Tahun 2018: 297-308.

Marlina, L., A. H. Dharmawan, dan Y. L. Purnamadewi. 2017. Peranan Kopi Rakyat terhadap Perekonomian Wilayah Kabupaten Lampung Barat. Jurnal Ilmu-Ilmu Agribisnis (JIIA) 5(3): 292-303.

Mayrowani, H. 2013. Kebijakan Penyediaan Teknologi Pacapanen Kopi dan Masalah Pengembangnya. Forum Penelitian Agro Ekonomi 31(01): 31-50.

Menteri Pertanian Republik Indonesia. 2017. Pedoman Produksi, Sertifikasi, Peredaran dan Pengawasan Benih Tanaman Kopi (Coffea Sp). Prosiding Kementerian Pertanian Republik Indonesia : 1-94 .

Mulyani, A. 2019. Analisis Faktor-Faktor yang Mempengaruhi Produktifitas Kopi Robusta Terhadap Peningkatan Pendapatan Ekonomi Dalam Prespektif Ekonomi Islam (Studi di Perkebunan Kopi Robusta Desa Talang Banung Bawah Kecamatan Sumber Jaya KKabupaten Lampung Barat). Skripsi. Ekonomi dan Bisnis Islam Universitas Islam Negeri Raden Intan. Lampung.

Mustofa, H. M. 2014. Perencanaan Produktivitas Kerja dari Hasil Evaluasi Produktivitas dengan Metode Fishbone di Perusahaan Percetakaan Kemasan PT.X. Jurnal Teknik Industri HEURISTIC 11(1): 27-46.

Novita, E., I. B. Suryaningrat, I. Andriyani, dan S. Widyotomo. 2012. Analisis Keberlanjutan Kawasan Usaha Perkebunan Kopi (KUPK) Rakyat di Desa Sidomulyo Kabupaten Jember. AGRITECH 32(2): 126-135.

Nuddin, A., Reskiana, Arman, S. Yusuf, Nuringsih, M. Arsyad, A. Bustan, dan A. Laapo. 2019. Designing New Strategy for Enhancing Robusta Coffee Produc- 
tion: an Application of Interpretative Structural Modeling. International Journal of Agriculture System (IJAS) 6(2): 156.

Oelviani, R. dan A. Hermawan. 2017. Kebutuhan Teknologi Kopi di Jawa Tengah (Studi Kasus Komoditas Kopi di Kabupaten Temanggung). Prosiding Semnas BAPPEDA Provinsi Jawa Tengah: 524533.

Oktaviani, K. 2018. Ngopi Sebagai Gaya Hidup Anak Muda Studi: Pada Pelanggan Coffeshop "Ruang Kopi" di Kota Bogor. Skripsi. Program Studi Sosiologi Universitas Negeri Jakarta. Jakarta.

Pamungkas, T. S., G. Wicaksono, dan R. Yunita. 2019. Pelatihan dan Pendampingan Kelompok Petani Kopi Desa Solor Kabupaten Bondowoso. Jurnal Inovasi Sosial dan Pengabdian Kepada Masyarakat 2(2): 101-106.

Parnadi, F. dan R. Loisa. 2018. Analisis Daya Saing Ekspor Kopi Indonesia di Pasar Internasional. Jurnal Manajemen Bisnis dan Kewirausahaan 2(4): 52-62.

Partelli, F. L., W. B. Marré, A. R. Falqueto, H. D. Vieira, dan P. C. Cavatti. 2013. Seasonal Vegetative Growth in Genotypes of Coffea Canephora, as Related to Climatic Factors. Journal of Agricultural Science 5(8): 108-116.

Pasaribu, W. N., Sumarjono, dan Mukson. 2019. Analisis Faktor-Faktor Produksi yang Mempengaruhi Produksi Kopi Robusta di Kecamatan Sumowono Kabupaten Semarang. Agromedia: Berkala Ilmiah Ilmu-Ilmu Pertanian 37(2): 8-15.

Pemerintah Kabupaten Temanggung. 2017a. Kopi Gesing Kandangan Juara Satu Nasional. Himpunan Berita Temanggung (HEBAT). http:/hebat. temanggungkab.go.id/news/372231.

Diakses tanggal 3 Desember 2019.

Pemerintah Kabupaten Temanggung. 2017b. Kopi Robusta dan Kopi Arabika. https://laman.temanggungkab.go.id/info/det ail/48/469/industri9.html. Diakses tanggal 3 Desember 2019.

Pemerintah Kabupaten Temanggung. 2017c.
Permintaan Kopi Temanggung Makin Tinggi. Magelang Ekspres. http://hebat. temanggungkab.go.id/news/371797.

Diakses tanggal 3 Desember 2019.

Permatasari, P. C., A. Basith, dan H. Mulyati. 2018. Model Bisnis Inklusif Rantai Nilai Kopi Arabika di Bondowoso Jawa Timur. Jurnal Manajemen Teknologi 17(2): 111-125.

Poltronieri, P. dan F. Rossi. 2016. Challenges in Specialty Coffee Processing and Quality Assurance. Challenges 7(2): 1-22.

Prasetyo, S. B., N. Aini, dan M. D. Maghfoer. 2017. Dampak Perubahan Iklim Terhadap Produktivitas Kopi Robusta (Coffea Robusta) di Kabupaten Malang. Jurnal Produksi Tanaman 5(5): 805-811.

Prasmatiwi, F. E., R. Evizal, dan T. Syam. 2017. Integrasi Ternak KambingTanaman Mendorong Budidaya Kopi Semiorganik. Prosiding Seminar Nasional Pengabdian kepada Masyarakat Universitas Lampung. Bandarlampung :1-5.

Pratiwi, R. R. 2016. Hambatan dan Strategi Pengembangan Usaha Tani Kopi dalam Upaya Peningkatan Produksi di Kecamatan Candiroto Kabupaten Temanggung. Skripsi. Ekonomi Pembangunan Universitas Negeri Semarang. Semarang.

Pujianti, E. 2019. Faktor-Faktor yang Mempengaruhi Produksi Dalam Persepektif Ekonomi Islam (Studi pada Usaha Tani Kopi di Muara Jaya II, Kecamatan Kebun Tebu, Lampung Barat). Skripsi. Fakultas Ekonomi dan Bisnis Islam Universitas Islam Negeri Raden Intan. Lampung.

Pusat Penelitian dan Pengembangan Perkebunan. 2010. Budidaya dan Pasca Panen Kopi. Prosiding Sistem Informasi Dokumentasi Penelitian dan Pengkajian: 1-59.

Putri, A., Y. Yusmani, C. Paloma, dan Z. Zakir. 2018. Kinerja Faktor Produksi Kopi Arabika (Coffea Arabica L.) di Lembah Gumanti, Kabupaten Solok, Sumatera Barat. Industria: Jurnal Teknologi dan Manajemen Agroindustri 7(3): 189-197. 
Ramanda, Hasyim, dan Lestari. 2016. Analisis Daya Saing dan Mutu Kopi di Kecamatan Sumberjaya Kabupaten Lampung Barat. Journal of Agribusiness Science 4(3): 253-261.

Ratnasari, E. D. 2018. Kopi Robusta Makin Populer tapi Memprihatinkan. CNN Indonesia, p. 1. https://www.cnnindonesia. com/gaya-hidup/20180427164012-262-

294173/kopi-robusta-makin-populer-tapimemprihatinkan. Diakses tanggal 6 Oktober 2019.

Resdianto, T. 2015. Analisis Perbandingan Pendapatan Antara Petani Kopi yang Mengolah Buah Kopi Dengan Menggunakan Alat Pulper Kopi dan Dengan Cara Tradisional di Desa Tangga Rasa Kecamatan Sikap Dalam Kabupaten Empat Lawang. Skripsi. Fakultas Pertanian Muhammadiyah Palembang. Sumatera Selatan.

Rosiana, N., R. Nurmalina, R. Winandi, dan A. Rifin. 2017. The Level of Comparative Advantages of World Main Coffee Producers. Buletin Ilmiah Litbang Perdagangan 11(7): 227-246.

Rosiana, N., R. Nurmalina, R. Winandi, dan A. Rifin. 2018. Dynamics of Indonesian Robusta Coffee Competition Among Major Competitor Countries. Journal of Industrial and Beverage Crops 5(1): 1-10.

Sachs, J. D., K. Cordes, J. Rising, P. Toledano, dan N. Maennling. 2020. Ensuring Economic Viability and Sustainability of Coffee Production. Prosiding Columbia Center on Sustainable Iinvestment: 3-139.

Sari, N. P. dan D. Nugroho. 2016. Condition of Soil Fertility and Sensory Profile of Smallholder Robusta Coffee in Jember District. Pelita Perkebunan 32(3): 181-191.

Sariani. 2017. Faktor-faktor yang Mempengaruhi Produksi Kopi di Kecamatan Tinggimoncong Kabupaten Gowa. Repositori Uin Alauddin Makassar 4(2): 1-10.

Sarirahayu, K. dan A. Aprianingsih. 2018. Strategy to Improving Smallholder Coffee Farmers Productivity. The Asian Journal of Technology Management (AJTM) 11(1): 1-9.
Sarvina, Y., T. June, E. Surmaini, R. Nurmalina, dan S. S. Hadi. 2020. Strategi Peningkatan Produktivitas Kopi serta Adaptasi terhadap Variabilitas dan Perubahan Iklim melalui Kalender Budidaya. Jurnal Sumberdaya Lahan 14(2): 65-78.

Sativa, O., Yuwana, dan Bonodikun. 2014. Karakteristik Fisik Buah Kopi, Kopi Beras dan Hasil Olahan Kopi Rakyat di Desa Sindang Jati, Kabupaten Rejang Lebong. Jurnal Agroindustri 4(2): 65-77.

Sahat, S. F., N. Nuryartono, dan M. P. Hutagaol. 2018. Analisis Pengembangan Ekspor Kopi di Indonesia. Jurnal Ekonomi dan Kebijakan Pembangunan 5(1): 63-89.

Savitry, L., T. Endaryanto, K. Murniati, dan Jurusan. 2020. Analisis Profitabilitas Olahan Kopi Robusta Sebagai Produk Unggulan Koperasi Tirto Kencono di Kabupaten Tanggamus. Journal of Agribusiness Science 8(4): 395-402.

Simamora, D. I. S., J. Yusri, dan N. Dewi. 2017. Analisis Faktor-Faktor yang Mempengaruhi Produksi Usaha Tani Karet di Kecamatan Pangkalan Kuras Kabupaten Pelalawan. Jurnal Online Mahasiswa Faperta Universitas Riau 4(2), 1-12.

Soliman, A., A. Mettleq, dan S. S. Abu-Naser. 2019. A Rule Based System for the Diagnosis of Coffee Diseases. International Journal of Academic Information Systems Research (IJAISR) 3(3): 1-8.

Ssebunya, B. R., E. Schmid, P. van Asten, C. Schader, C. Altenbuchner, dan M. Stolze. 2016. Stakeholder Engagement in Prioritizing Sustainability Assessment Themes for Smallholder Coffee Production in Uganda. Renewable Agriculture and Food Systems 32(5): 1-16.

Sugiarti, L. 2019. Identifikasi Hama dan Penyakit Pada Tanaman Kopi di Kebun Percobaan Fakultas Pertanian Universitas Winaya Mukti. Jurnal Agrowiralodra 2(1): 16-22.

Surya, J. A., Y. Nuraini, dan Widianto. 2017. Kajian Porositas Tanah pada Pemberian Beberapa Jenis Bahan Organik di 
Perkebunan Kopi Robusta. Jurnal Tanah dan Sumberdaya Lahan 4(1): 463-471.

Sutedja, N. 2017. Pengaruh Rootone F dan Atonik Dalam Pembibitan Kopi Robusta (Coffe canepora P). Skripsi. Universitas Udayana. Bali.

Swarsingkin, N. H., dan S. R. Budiani. 2015. Studi Komparatif Industri Kerajinan Serat Alam Kabupaten Bantul dan Kabupaten Kulonprogo. Jurnal Bumi Indonesia 4(1): 120-128.

Syahrial, R. E., F. Restuhadi, dan J. Yusri. 2017. Faktor-Faktor yang Mempengaruhi Produksi Usahatani Kopi di Kecamatan Rangsang Pesisir Kabupaten Kepulauan Meranti. Jurnal Online Mahasiswa (JOM) Universitas Riau 4(2): 1-4.

Syakir, M. dan E. Surmaini. 2017. Perubahan Iklim Dalam Konteks Sistem Produksi dan Pengembangan Kopi di Indonesia. Jurnal Penelitian dan Pengembangan Pertanian Kementerian Pertanian Republik Indonesia 36(2): 77-90.

Syarifudin dan O. Endarwati. 2019. Kopi Kita untuk Dunia. Kementerian Perindustrian Republik Indonesia, p. 1. https:// kemenperin.go.id/artikel/20330/Kopi-Kitauntuk-Dunia. Diakses tanggal 4 Desember 2019.

Tania, Y. V. 2018. Pengolahan Kopi Bubuk di PT.Perkebunan Nusantara IX (Persero). Prosiding Universitas Kkatolik Soegijapranata Semarang: 1-56.

Thamrin, S. 2014. Faktor-Faktor Yang Mempengaruhi Produksi Usahatani Kopi Arabika Di Kabupaten Enrekang Sulawesi Selatan. Open Journal Systems Universitas Kristen Satya Wacana 26(1): 16.

Thana, D. P., G. A. N. Pongdatu, A. Mantong, dan Hariadi. 2021. Identifikasi FaktorFaktor yang Memengaruhi Keberhasilan Usaha Kopi Jantan Toraja (Studi Kasus
Pada Umkm Kopi 1000 Nurhidayah). Forum Agribisnis Institut Pertanian Bogor 11(1): 13-25.

Tri, M., S. Raharto, dan T. Agustina. 2015. Prospek Pengembangan Komoditas Kopi Robusta di PT. Kaliputih Kecamatan Ledokombo Kabupaten Jember. JSEP Repository Universitas Jember 8(2): 11-24.

Tuningrat, I. A. M., K. Satriawan, D. P. Darmawan, dan A. A. P. A. Wiranatha. 2019. The Development of Robusta Coffee Agroindustry System in Bali Based on Structural Analysis and Institutional Interaction. AIP Conference Proceedings 215:1-13.

Universitas Diponegoro. 2013. Laporan Pengembangan Ekonomi Lokal (PEL) Partisipatif Kabupaten Temanggung Tahun 2013. Prosiding Badan Perencanaan Pembangunan, Penelitian dan Pengembangan Daerah Kabupaten Temanggung: 166.

Wiguna, S., S. Karimi, dan E. Ridwan. 2019. Dampak Skema Relasi Kopi Sebagai Pengembangan Perekonomian Petani Kopi di Pedesaan. Agriekonomika, Jurnal Sosial Ekonomi dan KebiJakan Pertanian, 8(1): 93-105.

Yordy, G. 2017. Analisis Faktor-Faktor yang Mempengaruhi Produksi Kopi Arabika di Sulawesi Selatan. Skripsi. Fakultas Ekonomi dan Bisnis Universitas Hasanudin. Makasar.

Yulanda, A. C. 2019. Analisis Faktor-Faktor yang Mempengaruhi Produksi Kopi Arabika (Studi Pada Petani Kopi Arabika Kecamatan Bumiaji Kota Batu). Jurnal Ilmiah Mahasiswa FEB Universitas Brawijaya 7(2): 1-13.

Zakki, M. 2020. Transformasi Dari Budaya Tradisional Ke Budaya Petani Industri. Jurnal Riset Entrepreneurship 3(1): 10-19. 